\title{
Laicidad positiva, igualdad consiguiente: diálogo sobre el artículo 16 de la Constitución española
}

\author{
Inclusive Secularity, Proportional Equality: \\ a dialogue on the Article 16 \\ of the Spanish Constitution
}

\author{
Andrés Ollero \\ Universidad Rey Juan Carlos \\ aollero@tribunalconstitucional.es
}

RECIBIDO: 21/09/2017 / ACEPTADO 20/11/2017

\begin{abstract}
Resumen: El concepto constitucional de «laicidad positiva» plantea una evidente ruptura con la dimensión negativa que ha acompañado históricamente a los puntos de vista laicistas, obligando a replantear el concepto de Estado laico. La vieja obsesión por una separación, que mantuviera un cordón sanitario entre los poderes públicos y el factor religioso, cede el paso a una cooperación que reconozca a religión como un factor tan positivo y digno de apoyo como la cultura o el deporte. Sentencias del Tribunal Constitucional español como la 46/2001 o la 34/2011 llevan a la práctica el mandato constitucional de que dicha cooperación sea consiguiente a las creencias de la sociedad española, descartando una mera equiparación aritmética en el trato con las confesiones.
\end{abstract}

Palabras clave: libertad de conciencia; libertad religiosa; laicidad positiva; laicismo; cooperación con confesiones; igualdad religiosa; artículo 9.2 Constitución española.

\begin{abstract}
The constitutional notion of «inclusive secularity» puts forward a rupture with the negative dimension that has normally characterized secularist points of view. This demands the rethinking of the notion of secular State. The old obsession with a separation that kept a cordon sanitaire between public authorities and the religious factor, yields to a cooperation that acknowledges religion as a factor as positive and worthy of support as culture or sport. Constitutional Court's Judgments such as 46/2001 and 34/2011 put into practice the constitutional mandate that requires a cooperation that reflects the Spanish society's beliefs, discarding a mere equal treatment in dealing with religious communities.
\end{abstract}

Keywords: freedom of conscience; religious freedom; inclusive secularity; secularism; state cooperation with religious communities; religious equality; art. 9.2 Spanish Constitution

bordar el contenido del artículo 16 de la Constitución española (en
adelante CE) obliga a descifrar un rompecabezas con términos y
principios clave. Habrá que ocuparse de la libertad ideológica y de 
confesiones religiosas; términos todos ellos presentes en el citado epígrafe constitucional.

Por si fuera poco, habrá que analizar también otros términos o principios no expresamente aludidos en él, pero de obligada evaluación a la hora de desentrañar su alcance: libertad de conciencia, laicidad, igualdad ${ }^{1}$, paridad, discriminación, neutralidad, tolerancia... Puede resultar paradójico que entre ellos se encuentren laicidad e igualdad, que son a los que de un modo u otro prestaremos particular atención. Habrá que barajarlos todos con cuidado, porque unos y otros solo encontrarán sentido aclarándolos en mutua referencia.

Esta dificultad inicial se verá reforzada por el convencimiento, éste sí unánime, de que nos encontramos ante de uno de los enconados problemas pendientes que preocupaban a los protagonistas de la transición española a la democracia. No es difícil, en efecto, constatar como signos de identidad de la Constitución de 1978 los intentos de resolver tres cuestiones: una configuración del Estado capaz de dar respuesta a insatisfechas tensiones nacionalistas, un enfoque del papel del ejército en una sociedad democrática y la históricamente identificada como cuestión religiosa ${ }^{2}$.

En lo que a esta última se refiere podrá afirmarse, casi cuarenta años después, que la Constitución no ha hecho «desaparecer del todo el combate ideológico cuando lo que se discute es la regulación jurídica del factor religioso» ${ }^{3}$. Reina a la vez el convencimiento de que «una convivencia política estable en España sólo será posible sobre la aceptación común de una concepción unívoca de la libertad religiosa, con todas sus implicaciones sociales y políticas ${ }^{4}$.

1 De la mezcla de unos y otros da fe el discutible dictamen de Ferrer OrTiz, J., «Pronto se impuso la opinión, prácticamente unánime, de que estos principios son los de libertad religiosa, laicidad del Estado, igualdad religiosa y cooperación con las Confesiones», en «Laicidad del Estado y cooperación con las confesiones», Anuario de Derecho Eclesiástico del Estado, III (1987), p. 238.

2 Cfr. entre tantos otros SuÁrez Pertierra, G., «La recuperación del modelo constitucional. La cuestión religiosa a los veinticinco años de la Constitución», en Laicidad y Libertades, Escritos Jurídicos, n⿳0 2 (diciembre 2002), p. 314.

3 Catalá, S., «La laicidad como principio inspirador del ordenamiento jurídico español», en Una filosofía del Derecho en acción. Homenaje al Profesor Andrés Ollero, Congreso de los Diputados, Madrid, 2015, p. 1711.

4 Fernández-Miranda CAmpoamor, A., «Estado laico y libertad religiosa», Revista de la Facultad de Derecho de la Universidad Complutense, 54 (1978), p. 5. 
No faltan sin embargo dictámenes más optimistas ${ }^{5}$, junto a significativos términos medios 6 .

En este peculiar contexto la búsqueda de la laicidad, falta de presencia expresa en el texto constitucional, supondrá identificar un principio con un triple carácter: implícito y discutido ${ }^{7}$ pero, pese a ello, omnipresente. Hay quien la ha calificado de noción que, además de ambigua, equívoca e incluso inútil, resultaría hoy anacrónica; cabría identificarla, si acaso, con la cooperación sin descartar su abandono ${ }^{8}$.

\section{1. ¿UNA CONSTITUCIÓN ALTERNATIVA?}

He dejado sentada desde el principio mi intención de ocuparme de un concreto artículo de nuestra Constitución. Es obvio que caben, lege ferenda, posibles textos alternativos. No faltan en efecto quienes adelantan su deseo de explorarlos ante cualquier oportunidad de reforma constitucional. Se genera,

5 «La Constitución de 1978 constituyó un hito memorable. Superó con brillantez, en pro de la pacificación y bajo el espíritu del consenso, las dos fórmulas de relaciones Iglesias-Estado existentes en la historia más reciente y que tanta tensión habían provocado: la confesionalidad católica del régimen franquista y el laicismo de la Segunda República», en OlmOs OrTEGA, M. E., «Una relectura de la laicidad y la cooperación a la luz de la libertad religiosa», en Derecho Eclesiástico a las puertas del Siglo XXI. Libro Homenaje al Profesor Fuan Goti Ordeñana, Fundación Universitaria Española, Madrid, 2006, p. 418. «Estamos ante la más perfecta fórmula de reconocimiento constitucional de este derecho en nuestra historia», cfr. TORRES GUTIÉRREZ, A., «Los retos del principio de laicidad en España: una reflexión crítica a la luz de los preceptos constitucionales», Anuario de Derecho Eclesiástico del Estado, XXXII (2016), p. 665.

6 La opinión dominante «considera que el pacto constitucional ayudó a diluir uno de los temas que habían provocado mayores fricciones en nuestra historia. Si comparamos las tensiones sociales que provocan los nacionalismos con la relevancia que otorgamos a las disputas por los temas eclesiales la diferencia es inmensa» cfr. GARCía SANTESMASES, A., Laicismo, agnosticismo y fundamentalismo, Biblioteca Nueva, Madrid, 2007, pp. 46-47.

7 Castro Jover, A., considera que para «el derecho español el término laicidad es desconocido, no aparece recogido en ningún texto jurídico». Su utilización habría «suscitado en la doctrina española reacciones diversas». Una parte lo habría acogido «como principio informador del Derecho eclesiástico» mientras otro sector doctrinal «ha rechazado su utilización porque lo consideran extraño a nuestro ordenamiento, prefiriendo utilizar el término aconfesionalidad»; no ha faltado quien proponga su abandono en «Laicidad y actividad positiva de los poderes públicos», Revista General de Derecho Canónico y Derecho Eclesiástico del Estado, 3 (octubre, 2003), pp. 4 y 1.

8 Cfr. Souto Paz, J.A., «La laicidad en la Constitución de 1978», en Estado y religión. Proceso de Secularización y Laicidad. Homenaje a Don Femando de los Ríos (ed. Dionisio Llamazares Fernández), Universidad Carlos III-Boletín Oficial del Estado, Madrid, 2001, pp. 226-228. 
en el fondo, el dilema planteado por Rawls entre el consenso entrecruzado, fundamento de una razón pública, o el repliegue en un modus vivendi, propio de quienes llegan a un acuerdo «dispuestos a perseguir sus objetivos a expensas del otro y, si las condiciones cambiaran, así lo harían»? ${ }^{9}$ Me limitaré pues a analizar lo que la Constitución dice, dejando al margen elucubraciones sobre lo que no quiso, o no pudo, decir.

Habrá pues que referirse a los que consideran obligado «reinterpretar la Constitución» con arreglo a sus presuntas «bases, incorporando a la reflexión los datos que ofrece el tiempo transcurrido»; aun reconociendo que «vendría a ser algo así como desandar el camino», para recuperar una enigmática «tensión constitucional» ${ }^{10}$.

No deja de resultar paradójico el fundamento de tal actitud, que se enlaza con el ya mítico consenso constitucional, característico de una transición democrática que algunos comienzan a considerar caducada. Se nos invita pues a pasar de lo que dice la Constitución a lo que, al parecer, habría dicho si hubiera podido; o sea, a lo que algunos quisieran que dijera.

Se reconoce al «consenso constitucional» como «elemento informador de las soluciones constitucionales y también principio interpretativo de las prescripciones que contiene la Constitución», pero considerando que «su aplicación es esencial para explicar el sentido de algunas soluciones constitucionales», relativizándolas. Todo ello radicaría en el lastre derivado de que «el entramado del art. 16.3» soportaría unas «cautelas de índole política» que «el legislador constitucional, que busca el consenso en tema tan delicado», no pudo evitar. Acabarían afectando a «la condición laica o neutral de un Estado separado de la Iglesia», con «el riesgo de que actúen intereses dirigidos a rebajar el sentido de las prescripciones constitucionales». Ello habría impedido llegar a «una declaración de laicidad técnicamente depurada, que es la propia de un Estado moderno respetuoso de la libertad y de la igualdad religiosas». Nos salen pues ya al paso alusiones a una separación, un determinado concepto de laicidad y una igualdad religiosa, ajenas a la letra constitucional; al menos a la que yo he leído.

La consecuencia de todo ello sería que tales cautelas coyunturales, introducidas como «instrumentos adjetivos de un planteamiento constitucional que tiene el mérito de haber permitido superar un problema endémico

9 Rawls, J., Political liberalism, Columbia University Press, New York, 1993, p. 147.

10 Sú́rez Pertierra, G. (2002), p. 314. 
en la sociedad española», permitirían «la veleidad de sustantivizar lo que en la Constitución aparece sólo como un elemento secundario requerido por la sensata práctica del consenso y con arreglo al cual debe ser interpretado $\gg^{11}$.

$\mathrm{El}$ asunto acaba teniendo bastante que ver con el adecuado ajuste de las libertades, ideológica y religiosa -de las que nos habla la Constitución en el primer epígrafe del artículo 16- con la libertad de conciencia, de la que en ella no hay literal noticia. $\mathrm{Al}$ efecto se nos ofrecen dos claves interpretativas, no exentas de consecuencias.

Se nos reconocerá, por una parte, que «la libertad religiosa y la libertad de pensamiento -como también la libertad de conciencia- tienen una raíz común, pero objetos diferentes». Para deslindarlos, se nos sugiere que «si a una fe religiosa se le quita la concepción ideológica y ética que puede producir, lo que le queda es el objeto estricto del derecho de libertad religiosa: el reconocimiento y garantía jurídicas de la libertad del acto de fe y del culto religioso correspondiente $\gg^{12}$.

En el enfoque alternativo la libertad de conciencia, ausente en el texto, se convierte en el elemento central, del que derivarían secundariamente las libertades ideológica y religiosa. Este nuevo angular no deja de tener repercusiones prácticas, que afectarán a los dos ámbitos problemáticos contemplados en él. En primer lugar, dentro del ámbito de la conciencia, no cabría justificar diferencia de trato entre ateísmo o agnosticismo y creencia religiosa ${ }^{13}$.

11 Ibid., pp. 330 y 334-335.

12 VILADRICH, P.J., y FERRER ORTIZ, J., «Los principios informadores del derecho eclesiástico español», en Derecho eclesiástico del Estado español, Eunsa, Pamplona, 1996, $4^{\mathrm{a}}$ ed., p. 144; las cursivas son mías. Los mismos autores reiteran años después la diferencia entre Weltanschauung, juicio de moralidad vinculado a libertad de conciencia y libertad religiosa en, «La igualdad religiosa. La cooperación del Estado con las confesiones en Derecho canónico y Derecho eclesiástico del Estado III: Eclesiástico». Materiales para el estudio del Derecho, en http://www.iustel.com, 2010, p. 4.

13 Esta peculiar «manera de entender la laicidad», que se atribuye sin mayor fundamento al Tribunal Constitucional, exigiría por ejemplo «que desaparezcan los acuerdos actualmente vigentes con la Iglesia Católica, previa su denuncia, o que sean revisados a fondo, desde el punto de vista de la forma y del contenido, tomando como modelo los acuerdos vigentes con las otras confesiones y no a la inversa». Se estima que «solo así conseguiremos la laicidad que es conditio sine qua non de la libertad de conciencia y de sus dos manifestaciones la libertad religiosa y la libertad ideológica» cfr. Llamazares Fernández, D., «Poder Político y Poder Religioso. Claves, Cauces y Modelos de Relación: Acuerdos Iglesia-Estado», en Laicidad y libertades. Escritos jurídicos (3) (2003), pp. 219 y 220. No falta quien, dentro del partido socialista, lamente que no se llevara a cabo: «El Gobierno, desde el primer momento, no planteó esa batalla que, por lo demás, no figuraba siquiera en el programa electoral del PSOE. El Gobierno priorizó la legalización del matrimonio homosexual y aparcó la derogación de los Acuerdos con la Santa Sede» cfr. García SANTEMASES, A. (2007), pp. 131-132. 
Consecuentemente, carecería también de sentido la prevista cooperación con las confesiones, salvo que se tratara al ateísmo como una creencia religiosa más ${ }^{14}$. «El último grave fallo del artículo 16.3 de la Constitución consiste en limitarse a hablar de creencias religiosas, como si la cuestión se plantease, en términos de convivencia, sólo en el ámbito de la religión. Este texto debería haber añadido a esa expresión la frase o cualesquiera otras, a fin de proteger expresamente los derechos de quienes, no teniendo creencia religiosa alguna, deseen promover o manifestar con el soporte de los medios de difusión -especialmente los financiados por los Poderes Públicos- sus sistemas de creencias, convicciones o concepciones relativas al mundo y a la vida que sean irreligiosas $\mathrm{o}$ antirreligiosas ${ }^{15}$.

Resulta obvia la dependencia de esta receta de la supuesta primacía de la libertad de conciencia. Se ha apuntado con acierto que radicada «la esencia de la libertad religiosa en la esfera de la autodeterminación del individuo a través de la evolución de la conciencia» y convertida en «principio estatal», cualquier «visión cosmológica de la existencia -ateísmo, agnosticismo o religión positiva- quedaría amparada por un derecho de libertad religiosa que impediría restricciones o manipulaciones de la conciencia personal», a la vez que exigiría «un tratamiento de cualquier creencia bajo el parámetro de la igualdad» ${ }^{16}$.

Una segunda consecuencia -ignorando la propia estructura del artículo $16 \mathrm{CE}$, cuyo tercer epígrafe se refiere a solo a las confesiones religiosas y no a los planteamientos ideológicos- será considerar rechazable que el mandato de cooperación establezca un tratamiento más positivo para las primeras que para los segundos. Se estaría obligando con ello a los poderes públicos «a mantener, sin posibilidad alguna de incurrir en dejación por su parte, una relación directa de colaboración con los grupos sociales institucionalizados» que «orientan específicamente su actuación a la persecución de fines religiosos»; «lo que no se predica, en proporción, respecto de los titulares asociados del derecho a la libertad ideológica». Esta «decisión adoptada por el constituyente» se consi-

14 Puente Ojea, G., en su peculiar apologética del ateísmo, criticará, con no poca sorpresa mía, a «seglares como el Rector de la Universidad Carlos III» (a la sazón Gregorio Peces-Barba) por considerar al laicismo como «otra religión», en «Esquema del laicismo», Iniciativa Socialista (75) (2005), p. 4.

15 Puente Ojea, G., «La llamada 'transición a la democracia' en España», en Elogio del ateísmo. Los espejos de una ilusión, Siglo XXI, Madrid, 2007, p. 344.

16 Motilla, A., «Breves notas en torno a la libertad religiosa en el estado promocional contemporáneo», en IBÁN I. C. (coord.), Libertad y derecho fundamental de libertad religiosa, Edersa, Madrid, 1989, p. 194. 
dera «más bien, tributaria de la consideración de la que se hacía merecedor el hecho religioso en el anterior sistema confesional»; «valoración positiva» que no podría «efectuarse en un Estado que se declare, al tiempo, laico» ${ }^{17}$.

Todo ello sería, desde esta óptica, «reflejo de un constituyente que, al igual que en otras cuestiones, se mostró excesivamente cauto y trató de llegar a un equilibrio que, en la práctica, lleva más de treinta años resultando inestable». Hasta el punto que se podría afirmar que, «en lo relativo a las relaciones entre los poderes públicos y las confesiones religiosas, nuestro país no ha completado la 'transición'. Seguimos muy condicionados por un artículo en el que, aunque se apuesta por el carácter aconfesional del Estado, se aboga también por mantener relaciones de cooperación con las confesiones y, de manera singular, con la Iglesia Católica que es la única que aparece expresamente citada en el texto» ${ }^{18}$.

La razón del problema radica, a ojos vista, en la dificultad de suscribir una laicidad positiva, que obliga a abandonar el viejo paradigma de la libertad religiosa entendida como libertad negativa, que no tendría otro alcance que la no intromisión de los poderes públicos en la privacidad religiosa. Desde luego «en un Estado hostil al fenómeno religioso, el aspecto positivo de la libertad religiosa tiene difícil salida»; mientras que «en un Estado promocionador del hecho religioso», «la dimensión negativa de esta clase de libertad suele encontrar ciertos obstáculos» ${ }^{19}$. De nuevo jugarán en el trasfondo dos elementos no explicitados en el texto constitucional: la libertad de conciencia y la igualdad religiosa ${ }^{20}$.

La posible réplica pondrá en cuestión el argumento preferido por los planteamientos laicistas: su presunta neutralidad. $\mathrm{El} \ll$ Estado no puede confun-

17 Porras Ramírez, J. Mª., Libertad religiosa, laicidad y cooperación con las confesiones en el Estado democrático de Derecho, Thomson-Civitas, Cizur Menor, 2006, pp. 185-186.

18 Salazar Benítez, O., «Las paradojas de la 'laicidad positiva' en la jurisprudencia del Tribunal Constitucional: ¿confesionalidad encubierta o aconfesionalidad líquida?», en RUIZ RICO, G. y RuIZ RuIZ, J. J. (dirs.), La libertad religiosa en las sociedades multiculturales. Las jurisprudencias nacional y europeas, Tirant lo Blanch, Valencia, 2015, p. 154.

19 SorIano, R., lo acaba reduciendo a «un problema de predominio de los intereses de las mayorías sobre los de las minorías, un problema sociológico, en último caso», en «Del pluralismo confesional al pluralismo religioso íntegro: los límites al principio de igualdad religiosa», Revista de las Cortes Generales (7) (1986), p. 101.

$20 \mathrm{El}$ «reconocimiento de las creencias religiosas de la sociedad española, que dice el precepto, no puede tener consecuencias de trato diferencial en relación con quienes no tienen creencias religiosas, porque lo impiden la libertad de conciencia y la igualdad» cfr. SUÁrez PerTiERrA, G. (2002), p. 335 . 
dir su radical incompetencia ante el acto de fe con aquellas formas de resolver el acto de fe de contenido negativo, agnóstico o indiferente». Cuando el Estado «decide ser ateo, agnóstico o indiferente -formas diversas de laicidad decimonónica- está coaccionando o sustituyendo a sus ciudadanos, puesto que definirse ateo, agnóstico o indiferente implica plantearse la competencia ante la fe y resolverla mediante un acto de ateísmo, agnosticismo o indiferentismo» ${ }^{21}$.

Esta cuestionable neutralidad igualitaria tendría como corolario la propuesta de someter a las confesiones religiosas al derecho común, descartando posibles Acuerdos o cualquier otra fórmula de cooperación, que es precisamente el objetivo que protagoniza de modo explícito el artículo $13.3 \mathrm{CE}^{22}$. Por el contrario, lo que la Constitución con claridad señala para las confesiones es «un tratamiento jurídico específico y favorable. Es decir, la cooperación implica, por definición, una excepción a las normas generalmente aplicables. Éste ha de ser criterio hermenéutico necesario para la interpretación de la normativa concordada con la Santa Sede, los acuerdos con otras confesiones, y en general las posibilidades de cooperación del Estado con el hecho social religioso ${ }^{23}$. Se comprende que haya quien discrepe, por entender que se estaría separando al derecho de libertad religiosa «indebidamente del derecho de libertad ideológica». Resulta coherente por lo demás que se anime a «enfrentar la reforma constitucional $\gg^{24}$, por obligada.

Parentesco con la pretendida neutralidad laicista guardan algunas referencias a la tolerancia. No viene mal pues recordar la diferencia entre ella y la justicia ${ }^{25}$.

21 Viladrich, P.J., «Ateísmo y libertad religiosa en la Constitución Española de 1978», Revista de Derecho Público (IX-1) (1983), p. 91.

$22 \ll$ Si la libertad de ideas y la libertad de creencias religiosas son dos facetas de una misma libertad, el tratamiento específico de la libertad religiosa, como hace nuestro ordenamiento, genera una impropia diferenciación dentro de una realidad unitaria, que tiene como consecuencia la extracción del Derecho común de uno sólo de ambos elementos» cfr. Suárez PerTierRa, G. (2002), p. 343. «Las iglesias y demás instituciones religiosas o confesionales son meras asociaciones de creyentes que tienen que someterse rigurosamente a las normas del Derecho civil o común para su constitución y sus actividades» cfr. Puente OJEa, G. (2005), p. 2.

23 Martínez-TorRón, J., «Concordato, cooperación e igualdad. La cooperación del Estado español con las confesiones religiosas a la luz del vigente sistema de acuerdos con la Iglesia Católica», Revista General de Derecho Canónico y Derecho Eclesiástico del Estado (4) (2004), pp. 3-4.

24 Mientras «permanezcan las causas constitucionales del problema, que seguirían actuando como un peligroso punto de referencia para quienes quisieran una nueva vuelta de interpretación. Así pues, hay que recuperar el buen sentido constitucional», del que se autoerige en intérprete cfr. SuÁrez Pertierra, G. (2002), p. 348.

25 De ello ya me ocupé: «Tolerancia y verdad», en Derecho a la verdad. Valores para una sociedad pluralista, Eunsa, Pamplona, 2005, pp. 71-112. 
Mientras ésta invita a reconocer a cada uno lo que es suyo, su derecho, la tolerancia exhorta a respetar al vecino, en aras de su dignidad personal, en aquello que no ha generado propiamente un derecho; salvo que reconozcamos condición jurídica al derecho a equivocarse o a comportarse de modo considerado inadecuado. De ahí que la idea de tolerancia haya sido vinculada al rechazo de lo intolerable ${ }^{26}$, aspecto que el entusiasmo por la tolerancia puede llevar a veces a olvidar ${ }^{27}$. Desde ese punto de vista, he expresado más de una vez -como creyente, titular de un derecho fundamental a la libertad religiosa- mi decisión de no tolerar que me toleren.

Se nos dirá, por ejemplo, que en «una sociedad democrática la laicidad implica tolerancia de creencias, que es lo contrario de una sociedad fundamentalista. En el Estado laico, las creencias religiosas y cosmovisiones metafísicas se localizan en el ámbito privado; forman parte del derecho a la libertad ideológica y de conciencia, que alberga la libre profesión de creencias, pero también el agnosticismo y las ideas antirreligiosas ${ }^{28}$.

En no pocas ocasiones este repliegue laicista de la religión a lo privado, no llega a disimular el afán de llegar a hacer decir a la Constitución lo que no quiso. Habría que «salir al paso del asentamiento de una fórmula que favorece el tratamiento específico del factor religioso frente a lo ideológico» y al intento de convertir a la cooperación en «elemento principal», cuando «los dos componentes nucleares del sistema» serían «libertad de conciencia y laici$d a d »$, entendida en clave laicista, con lo que se diluiría «la presión de la neutralidad y se propicia la inclusión de intereses específicamente religiosos en

26 «Las regulaciones jurídicamente vinculantes requieren en última instancia la delimitación entre lo que debe ser tolerado y lo que no puede ser tolerado» cfr. HABERMAS, J., «De la tolerancia religiosa a los derechos culturales», Claves de Razón Práctica (129) (2003), p. 7. Muy gráfico al respecto GARZÓN VALDÉs, E., «No pongas tus sucias manos sobre Mozart», Claves de Razón Práctica (19) (1992), pp. 16-23.

27 Me asombró, a pesar de ello, que Torres Gutierrez, A., «Libertad religiosa y laicidad del Estado en la Constitución de 1978», en XXV Aniversario de la Constitución Española. Propuestas de reformas, Centro de Ediciones de la Diputación Provincial de Málaga (CEDMA), Málaga, 2004, p. 612, rompiera una lanza en favor de «las fórmulas poligámicas, que doctrinalmente se rechazan mayoritariamente por el derecho positivo vigente», atribuyéndolo a «un concepto del orden público tomado de una tradición judeo-cristiana», que llevaría a ignorar «otros esquemas religiosos y culturales como el musulmán, quizás por ser minoritaria su presencia»; por lo visto, aun admitiendo el exotismo de la poliandria, no estaría en juego la dignidad de la mujer.

28 Marcilla Córdoba, G.M., «Tolerancia y laicidad en el ámbito jurídico-público», en Una filosofía del Derecho en acción. Homenaje al Profesor Andrés Ollero, Congreso de los Diputados, Madrid, 2015, p. 1867. 
el conjunto de las obligaciones que corresponden a los poderes públicos» ${ }^{29}$. Curiosamente ninguno de los conceptos que hemos resaltado figura en el texto constitucional.

\section{QUiÉN ES LAICO}

El término laico aparece cargado de una doble dimensión semántica, en ambos casos negativa. La primera se refiere a individuos y es, paradójicamente, de origen clerical. Se consideran laicos, en las confesiones cristianas, a quienes no son clérigos: los fieles corrientes, que no habrían recibido las órdenes sagradas. La segunda se refiere a Estados, entendiendo -con sabor decimonónico- como laicos a los que evitan toda contaminación con elementos religiosos; respecto a los que pueden llegar a mantener una actitud rayana en la hostilidad.

La primera acepción resulta fiel a su raíz griega. Laico procedería del término laos, que expresa una determinada versión de pueblo ajena a lo institucional (demos). Identificaría por tanto al pueblo llano, sin connotaciones oficiales. De ahí que pasara al latín no como laicus sino como pebleius ${ }^{30}$. Desde esta perspectiva habría sido acertado considerar como Estado laico al que no complica la vida a los laicos. Hoy por hoy, en perspectiva individual, el laico sería simplemente -o nada menos que- un ciudadano; aunque, al secularizarse el término, pueda entenderse por tal al no contaminado con elementos religiosos, o que incluso se muestra hostil a su presencia pública.

La dimensión negativa de la laicidad vendrá en ambos casos de la mano del clericalismo. El que no es clérigo pueden acabar viéndose tratado -con excesiva fidelidad a la parábola- con una oveja del rebaño; incluso en el ámbito de lo temporal, que le es propio ${ }^{31}$. Como veremos, puede acabar siendo tam-

29 Como consecuencia, «en contra de la correcta interpretación constitucional», de la que el autor se erige en intérprete auténtico, «este modelo sustantiviza aquellos componentes del sistema que son accesorios, que sólo deben comportarse como cautelas constitucionales». Este sería «uno de los peligros que la artificiosa fórmula constitucional podía llegar a comportar» cfr. SUÁReZ Pertierra, G. (2002), pp. 347-348.

30 Hervada, J., Tres estudios sobre el uso del término laico, Universidad de Navarra, Pamplona, 1973, pp. 19, 47, 52 y 117.

31 Para Limodio, G., el clericalismo «parte del supuesto de que con la elevación de lo humano al orden sobrenatural, el orden natural pierde todas sus prerrogativas, y por ende, quien ejerce una jerarquía religiosa tiene el derecho y el deber de guiar a la sociedad por entero, tanto en la órbita 
bién víctima de un clericalismo civil, cuya querencia totalitaria le invita a tratar al ciudadano como mero súbdito. En consecuencia, el Estado se apropia de lo público $^{32}$ sin respetar la dimensión social de la actividad de los ciudadanos; que incluye la expresión de sus creencias religiosas y la comunitaria prestación de culto público, contempladas por nuestra Constitución.

En esa línea se proyecta la mentalidad laicista, que tiende a establecer una drástica frontera entre lo público y lo privado, confinando en este último ámbito cualquier manifestación religiosa. Su artificiosidad es notoria. La libertad religiosa constitucionalmente aparece, como otras, «vinculada a la libertad de asociación», con una dimensión colectiva «que no puede recluirse» en «la esfera privada de las personas. Esto nos llevará a cuestionar la tesis de la privatización con la que frecuentemente se ha traducido la laicidad, como si el muro de separación entre lo político y lo religioso coincidiera con la división entre público y privado». Se trata, sin duda, de «uno de los motivos de conflicto entre interpretaciones discrepantes sobre el alcance político de la libertad religiosa $\gg^{33}$.

No ha faltado quien -haciendo alarde de sentido común, aun suscribiendo el laicismo ${ }^{34}$ - reconozca que «muchos laicistas se aferran a un imposible político: a reducir la religión al mundo de lo privado». A su juicio, el «proble-

religiosa como temporal. Por su parte el laicismo se ha transformado en una ideología que lleva gradualmente de una forma más o menos consciente a la restricción de la libertad religiosa hasta promover un desprecio o una ignorancia de lo religioso, relegando la fe a la esfera de lo privado y oponiéndose a su expresión pública», en «La enseñanza del Derecho civil y el paradigma de la legítima laicidad», en Una filosofía del Derecho en acción. Homenaje al Profesor Andrés Ollero, Congreso de los Diputados, Madrid, 2015, p. 1862.

32 Ya me ocupé de ello: «La apropiación de lo público por el Estado», en Cuatro Conferencias sobre Ética y Empresa, Los Jarales, Málaga, 1991, pp. 31-55.

33 Gamper, D., Laicidad europea. Apuntes de filosofía politica postsecular, Bellaterra, Barcelona, 2016, p. 52. De ahí que se haya afirmado: «Es evidente que la Constitución con la proclamación de un Estado laico no consagró un modelo de Estado enfrentado al fenómeno religioso o que considerara a la religión como un mero asunto privado», en GARCÍA GARATE, A., «El largo y tortuoso camino hacia la laicidad (A propósito de la STC 177/1996, de 11 de noviembre)», en La libertad religiosa y de conciencia ante la fusticia constitucional. Actas del VIII Congreso Internacional de Derecho Eclesiástico del Estado, Comares, Granada, 1998, p. 491.

34 Ya es hora de hacer notar que «la doctrina diferencia entre laicidad y laicismo: la primera respetuosa con el hecho social religioso y la libertad de los ciudadanos y el segundo hostil, combatiente o persecutorio» cfr. BARRERO ORTEGA, A., «Laicidad versus cooperación», Anuario de Derecho Eclesiástico del Estado, XXXI (2015), p. 43. Entre los segundos se deja incluir PUENTE OJEA, G. (2007), p. 381, «pese a la existencia de muchas gentes buenas en su seno, la institución eclesiástica es en sí misma perniciosa y al mismo tiempo insanable, porque no puede dejar de ser lo que es». 
ma no es si tiene expresión pública sino cuál». «No tiene sentido apostar por un modelo laico donde la religión queda reducida a la conciencia individual y donde el espacio público sea un espacio incontaminado porque no aparece nunca ningún símbolo religioso ${ }^{35}$.

Por otra parte, un sereno conocimiento histórico lleva a constatar que la laicidad es una aportación cristiana. El «dad al césar que es del césar y a Dios lo que es de Dios» surge innovadoramente en un contexto generalizado de fusión de lo político con lo religioso, que generó no pocos mártires; empezando por su autor. Bien es cierto que «al mismo tiempo, el cristianismo afirma la supremacía de lo espiritual respecto a lo temporal y la consiguiente relativización del poder político, esto es, la subordinación de ese poder a criterios -superiores e independientes- de verdad moral, de derecho natural, de justicia, y también de tipo escatológico. Por estas razones, el cristianismo se erigió en condición de posibilidad para el desarrollo de una cultura política laica y, como veremos, por muy paradójico que pueda parecer, sigue siendo todavía hoy su garante ${ }^{36}$. Es también obvio -como se ha apuntado compartiéndolo- que las «grandes religiones tienen que apropiarse de los fundamentos normativos del Estado liberal aun cuando exista, de nuevo bajo sus propias premisas, un vínculo genealógico entre ambos (tal como sucede en el caso de la tradición judeo-cristiana) $\gg^{37}$.

En efecto, la «paradoja cristiana radica en el hecho de que el cristianismo afirma la intrínseca bondad, racionalidad y autonomía de las realidades te-

35 Tras autoincluirse entre «los ex cristianos con intereses religiosos», porque «me parece que ese diálogo sobre las diversas visiones del sentido es imprescindible» cfr. GARCÍA SANTESMASES, A. (2007), pp. 142-142 y 153. En línea similar Díaz SALAZAR, R. (2010), pp. 72 y 67 constata que en «nuestro país está muy difundida la tesis de 'la religión es un asunto privado'; algo insostenible desde la sociología. Sólo desde un laicismo excluyente se puede privatizar forzadamente a una religión o a una iglesia»; propone en consecuencia un «laicismo socialista como integración y superación del laicismo liberal», que llevaría a «la convergencia con los movimientos cristianos emancipatorios».

36 Rhonheimer, que se muestra convencido de que «la cultura política del Estado constitucional democrático, la cultura laica, liberal y democrática de tipo occidental, mantiene con el cristianismo un vínculo genético, que es determinante y constitutivo», en Cristianismo y laicidad. Historia y actualidad de una relación compleja, Rialp, Madrid, 2009, pp. 15 y 18.

37 Habermas, J. (2003), p. 8. F. J. Contreras concluye: «Los católicos no debemos temer una laicidad rectamente entendida; en realidad, la laicidad es una de las grandes aportaciones del cristianismo a la cultura occidental». «En Israel - y, después, en la cristiandad - el poder es desacralizado: sólo Dios es Dios; el Estado no es divino; el Estado es falible (y, por tanto, su autoridad debe ser sometida a control y limitación)», en «El derecho a ser laico», Anuario de Derecho Eclesiástico del Estado, XXXI (2015), p. 59. 
rrenas: no las somete, por tanto, a la esfera religiosa, desde un punto de vista gnoseológico, metafísico y práctico. Sin embargo, al mismo tiempo contempla estas realidades terrenas como necesitadas de que una verdad superior las ilumine y necesitadas de redención ${ }^{38}$.

No viene mal esta aclaración, dado el incierto contenido del término $E s$ tado laico, cuya «elasticidad» lo «ha convertido en un verdadero cajón de sastre, en el que cabe toda guisa de relaciones imaginables entre sociedad política y sociedad religiosa: desde el Estado hostil a la religión al Estado amistosamente cooperador y promocionador de los grupos religiosos» ${ }^{39}$.

La laicidad permite poner freno a cualquier deriva totalitaria del laicismo. Más que pretender manejarla como «un concepto en gran medida técnico, y propio del lenguaje jurídico», que cabría explicar «como se podría definir la hipoteca», conviene resaltar cómo con frecuencia «en el debate de la laicidad hoy lo que está en juego es el rechazo a priori de una ética en la vida pública que tenga origen religioso $»^{40}$. La «grandeza, verdad y perenne validez» de la laicidad «residen justamente en su carácter antitotalitario o, lo que es lo mismo, en el principio de la subordinación del poder político a criterios morales externos, independientes, superiores, y en especial a criterios de justicia, que entrañan la importante particularidad de que no se encuentran a la libre disposición de quienes ejercen el poder político» ${ }^{41}$.

No faltará, sin embargo, quien no se arredre a la hora de plantear una apología del laicismo, al considerarlo «un principio indisociable de un sistema político verdaderamente democrático». De ahí que le parezca «sorprendente que multitud de gentes, y a veces muy cultivadas, ignoren realmente su esencia y sus consecuencias». El principio laicista, postularía, «en cuanto señal y cifra de la modernidad como hito histórico irreversible del autoconocimiento y la autoliberación del ser humano, la protección de la conciencia libre del individuo y de su privacidad, desalojando radicalmente de la res pu-

38 Rhonheimer, M. (2009), p. 25. No admitiría en consecuencia la peculiar versión de DíAz SALAZAR, R., de la propuesta habermasiana de doble aprendizaje. A juicio de este, el aprendizaje católico habría de admitir que «la religiosidad evangélica sólo se difundirá adecuadamente si se hace desde la carencia de poder», mediante una «aceptación sincera de la autonomía política y legislativa del Estado», que impide «criticar sus decisiones», en «Laicismo y catolicismo ¿Una nueva confrontación?», Claves de Razón Práctica (208) (2010), p. 69.

39 SORIANO, R. (1986), p. 125.

40 RoCa FERnÁNDEZ, M.J., «Laicidad del Estado y garantías en el ejercicio de la libertad: dos caras de la misma moneda», El Cronista del Estado Social y Democrático de Derecho (3) (2009), p. 46.

41 Rhonheimer, M. (2009), p. 62. 
blica toda pretensión de instaurar en ella un régimen normativo privilegiado a favor de cualquier fe religiosa que aspira a institucionalizarse en forma de ente público» ${ }^{42}$.

En realidad, así como en la conversión de la libertad religiosa de los ciudadanos en centro de gravedad del problema radica el auténtico eje de la laicidad, la consideración del Estado como laico deriva del reconocimiento de la autonomía de lo temporal. Se ha podido pues afirmar que «es sencillamente una consecuencia del carácter profano y no sacro de la realidad estatal. El Estado, como realidad del orden natural, es por su misma naturaleza laico, en el sentido de que está sometido a sus propias leyes, como lo están igualmente las demás realidades del orden natural»; todo Estado sería pues «naturalmente un Estado laico, no confesional». «La laicidad del Estado no es entonces una cualidad negativa del Estado para oponerse a la religión o para luchar contra ella de un modo más o menos confesado, sino que es sencillamente la consecuencia natural de lo que el Estado mismo es» ${ }^{43}$.

La laicidad sería pues una característica adjudicable al Estado español, mientras que «la aconfesionalidad por ser negativa» o la «neutralidad por ser parcial, no expresan en su totalidad el ser y actuar del Estado respecto de las creencias ideológicas y religiosas; carácter que» «sí puede quedar comprendido bajo el término Estado laico» ${ }^{44}$. Es obvio, por otra parte, que la problematizada neutralidad nunca podría ser absoluta en sociedades crecientemente

42 Esto lleva a declarar su «rechazo de fórmulas engañosas y manipuladoras, de las que representa un arquetipo la bautizada como laicidad abierta, que equivale a otorgar un estatuto privilegiado a todas las religiones», en PUENTE OJEA, G., «El laicismo, principio indisoluble de la democracia», Libre Pensamiento (51) (2006), pp. 87 y 91. Interesante sobre tales intentos es VALERO ESTARELLAS, M. J., «Laicidad, neutralidad y libertad religiosa y de conciencia en Francia tras 'Charlie Hebdo': ¿hacia la consolidación legal de una 'nouvelle neutralité'?», Anuario de Derecho Eclesiástico del Estado, XXXII (2016), pp. 723-761.

43 De ahí su afirmación de que el español sería un Estado laico «por omisión, por no declararse expresamente en nuestra Constitución que España es un Estado confesional», en Molano, E., «La laicidad del Estado en la Constitución Española», Anuario de Derecho Eclesiástico del Estado, II (1986), pp. 243-244, 246 y 245; también 251.

44 Motilla, A., «Estado laico y libertad religiosa», Anuario de Derecho Eclesiástico del Estado, XXIV (2008), p. 77. Este planteamiento, que comparto, tropieza con reticencias que proceden en parte de los que, como López-Sidro LóPEZ, A., recelan de «quienes piensan en clave de laicismo cuando hablan de Estado laico. Esta equivalencia se da a menudo, y por eso encuentro más ajustado hablar de Estado aconfesional, para evitar otras interpretaciones interesadas que no están en la Constitución», en «La libertad religiosa en el Derecho español, entre la laicidad y el pluralismo», en Ruiz Rico, G. y RUIZ RuIZ, J. J. (dirs.), La libertad religiosa en las sociedades multiculturales..., op. cit., p. 299. 
multiculturales ${ }^{45}$; en la nuestra, por el juego de la cláusula de orden público, recogida por el mismo artículo $16 \mathrm{CE}$-en su epígrafe primero- como único límite a las libertades que ampara.

En todo caso, para que tal laicidad pueda considerarse realmente positiva será decisivo, como vimos, que la garantía del derecho de libertad religiosa se convierta de modo efectivo en el centro de gravedad del sistema ${ }^{46}$. De lo contrario podría quedar reducida a retórica, siendo los ciudadanos víctimas de un clericalismo compartido, que reduciría todo a consensuar un modus vivendi entre el Estado y las iglesias. Mientras que se alcanza tal proeza en las cumbres del sinaí político, los ciudadanos (súbditos-ovejas en realidad) aguardarían al pie de la montaña la respuesta al qué hay de lo mío ${ }^{47}$.

La clave del asunto consistirá pues en que el Estado renuncie a apropiarse de lo social y pase a respetarlo. Así ocurre con otras manifestaciones sociales, como el deporte, y sería deseable que ocurriera también con la cultura. Respeto en modo alguno incompatible con una cooperación ${ }^{48}$ no discriminatoria. Siendo la laicidad el fundamento de dicha cooperación, no tiene demasiado sentido sugerir ${ }^{49}$ que «los principios de igualdad y laicidad deberían operar como límite del principio de cooperación».

$45 \mathrm{El}$ «secularismo e inclusive la aconfesionalidad no puede ser sinónimo de neutralidad absoluta. El Estado no puede permanecer indiferente ante aquellas expresiones de la identidad cultural y el particularismo religiosos que resulten diametralmente antagónicos con el sistema de valores constitucionales que comparte el conjunto de la sociedad; ni siquiera cuando esas conductas incompatibles jurídica y culturalmente con las reglas de convivencia fundamentales permanecen dentro del estricto ámbito de las relaciones privadas o familiares» cfr. RUIZ-RICO RuIZ, G., «La libertad religiosa como dimensión constitucional de la diversidad cultural», en RUIZ RICO, G. y RUIZ RUIZ, J. J. (dirs.), La libertad religiosa en las sociedades multiculturales..., op. cit., pp. 32-33.

$46 \mathrm{El}$ «principio de libertad religiosa al constituirse en el principio primario no sólo desplaza de esta función al de laicidad, sino que, al sustituirlo, modifica el sentido que la laicidad tenía según su planteamiento decimonónico». «Para sustituir en su papel de principio primario a la confesionalidad del Estado, aquella voluntad de terminar entre los españoles la 'cuestión religiosa' ha elegido para la función de primer principio definidor del Estado en materia eclesiástica al de libertad religiosa, en vez de recurrir a la de laicidad del Estado» cfr. VILADRICH, P.J. (1983), pp. 92 y 68-69.

47 LlamaZares, D. (2003), pp. 207 y 208, constata este mismo cuadro: «Jamás aparece referencia alguna a derechos de los fieles-súbditos que, evidentemente, no son objeto de preocupación para ninguna de las partes». Su receta será, sin embargo, primacía de libertad de conciencia y una «verdadera laicidad, entendida, a un tiempo, como neutralidad y como separación del Estado respecto de la Iglesia».

$48 \mathrm{Si}$ «la libertad religiosa se convierte en el eje central del modelo español de relaciones Iglesias Estado estamos realmente ampliando ese binomio y hablando del trinomio libertad, laicidad y cooperación» cfr. Olmos, M.E. (2006), p. 426.

49 Como hace Salazar, O. (2015), p. 185. 
«Se puede afirmar, en consecuencia, que la laicidad ya no es el calificativo religioso del Estado, sino el calificativo estatal de la regulación jurídica del factor religioso, entendido y tratado exclusivamente como factor social que forma parte también del bien común». Por eso nuestro Estado está «obligado a considerar como un factor social específico las creencias religiosas de la sociedad española $\gg^{50}$.

\section{LAICIDAD POSITIVA. LA STC 46/2001, DE 15 DE FEBRERO}

«El término laicidad 'positiva' se ha utilizado en la doctrina española e italiana para referirse al Estado que debe colaborar con las Confesiones religiosas. Esta manera de entender la laicidad deja a las claras su oposición frente al laicismo» ${ }^{51}$. Arquetípica al respecto resultará la Sentencia del Tribunal Constitucional (en adelante STC) 46/2001, de 15 de febrero. Con cita de sentencias anteriores nos indicará que «el art. 16.3 de la Constitución, tras formular una declaración de neutralidad (SSTC 340/1993, de 16 de noviembre, y 177/1996, de 11 de noviembre), considera el componente religioso perceptible en la sociedad española y ordena a los poderes públicos mantener 'las consiguientes relaciones de cooperación con la Iglesia Católica y las demás

50 VILADRICH, P. J. (1983), pp. 96-97, que inserta como inciso: «el medio o instrumento más 'laico' que el Estado tiene para tratar el factor, religioso es el Derecho». Para Molano, E. (1986), pp. 251-252, lo que la Constitución «afirma realmente es el carácter social y no estatal de las confesiones religiosas, y como consecuencia de ello la mutua independencia entre Estado y confesiones». Las «creencias religiosas que se manifiestan en la sociedad no quedan relegadas exclusivamente al ámbito de la esfera privada de las personas, sino que se les atribuye relevancia pública: los poderes públicos han de tenerlas en cuenta. Ese tener en cuenta es un matiz importante para entender la laicidad del Estado español. La Constitución española ha rechazado un planteamiento de Estado laico que permitiese al Estado la ignorancia o la indiferencia ante el factor religioso de la sociedad: una actitud de ignorancia o de indiferencia por parte de los poderes públicos sería anticonstitucional» a su juicio.

51 Catalá, S. (2015), p. 1721. Lo suscribe Mantecón Sancho, J.: «En feliz expresión de nuestro Tribunal Constitucional, la complementariedad de la no confesionalidad con el principio de cooperación da lugar a lo que el Alto Tribunal denomina laicidad positiva», en «Derecho Canónico y laicidad del Estado», El Cronista del Estado Social y Democrático de Derecho (55) (2015), p. 40. También, a su manera, Porras, J. M. (2006), p. 189: «Dicha idea de cooperación, equidistante, tanto de la unión, como de la incomunicación, entre el Estado y las confesiones, se integra en el paradójico concepto, oportunamente definido por el Tribunal Constitucional, de laicidad positiva». Menos entusiasta SALAZAR, O. (2015), p. 158: «el mismo Tribunal Constitucional ha sido cómplice a lo largo de estas tres décadas con el mantenimiento de dicho estado de cosas». 
confesiones', introduciendo de este modo una idea de aconfesionalidad o laicidad positiva que 'veda cualquier tipo de confusión entre fines religiosos y estatales' (STC 177/1996)» $\gg^{52}$.

La dimensión positiva de nuestra laicidad constitucional queda en seguida de relieve, al señalarse que respecto a las actividades religiosas «se exige a los poderes públicos una actitud positiva, desde una perspectiva que pudiéramos llamar asistencial o prestacional» ${ }^{53}$. La libertad religiosa deja pues de considerarse como mera libertad negativa, sin otro eco en los poderes públicos que el veto a cualquier injerencia, para poder convertirse en un peculiar derecho de prestación, como consecuencia del establecido compromiso de cooperación con las confesiones. Por otra parte, en un contexto menos técnico, se podrá insinuar que si hay una laicidad positiva es porque hay otra negativa: la propia de los planteamientos laicistas opuestos a dicha cooperación ${ }^{54}$.

En todo caso, uno y otro punto de vista abren el debate sobre la existencia de un Estado que, declarándose aconfesional, exhibe una consideración positiva del factor religioso, hasta el punto de que la equiparación entre la libertad ideológica y la religiosa en los dos primeros epígrafes del artículo $16 \mathrm{CE}$ desaparece en el epígrafe tercero. Aunque se distinga entre la valoración positiva del «hecho religioso» y la del «derecho fundamental de libertad religiosa», parece claro que «en la práctica, es muy difícil deslindar la promoción de la libertad religiosa y la promoción de lo religioso», dado que «cualquier medida de ordenamiento favorable al factor religioso puede interpretarse en clave de libertad religiosa $\gg^{55}$.

52 STC 46/2001, Fundamento (en adelante F.) 4. A propósito la última afirmación SUÁREZ PERTIERRA, G. (2002), p. 338, partiendo una vez más de una presunta prioridad de la libertad de conciencia, entiende que esto no implica una «valoración positiva de lo religioso en sí, que el Estado no puede hacer porque sería contradictorio con el entendimiento exacto del propio derecho de libertad de conciencia constitucionalmente incorporado»; sin soporte literal, como ya vimos. Por el contrario, Moreno Mozos, M.M., considera que la «Constitución pretende determinar una actitud activa y positiva de los poderes públicos frente a lo religioso, sustituyendo la confesionalidad por la laicidad y afirmando la libertad religiosa como principio primario en la definición del Estado en materia religiosa», en La Doctrina Eclesiástica Española en el Último Ventenio. Historia de una Revista: «El Anuario de Derecho Eclesiástico del Estado», Thomson-Aranzadi, Madrid, 2006, p. 73.

53 STC 46/2001, ibidem.

54 Así lo suscribimos en Un Estado laico. La libertad religiosa en perspectiva constitucional Aranzadi Thomson Reuters, Cizur Menor, 2009, p. 51, entre otras.

55 BARRERO, A. (2015), pp. 12 y 50. No parece tan convincente sugerir, como hace CASTRO, A. (2003), p. 16, que partiendo de que «el art. 16.3 no hace más que explicitar principios que se aplican también en relación con otros grupos sociales, su mención expresa para los grupos reli- 
Intentando encontrar la clave de esta peculiar especifidad de trato ${ }^{56}$, se ha apuntado al «interés del legislador en garantizar cierta unidad cultural del país con el paso del tiempo. El Estado se ofrece para cooperar con las confesiones religiosas en general y con la Iglesia católica en particular de modo que se configura una laicidad que no es indiferente ni neutra frente a la religión, sino que considera que lo religioso es un fenómeno importante cuya tutela requiere la intervención garantista de las instituciones». En esto consistiría «lo que se ha dado en llamar la laicidad positiva ${ }^{57}$. No se ha descartado tampoco una dimensión más personal que colectiva. Si «el Estado tiene en cuenta las creencias religiosas significa que valora el hecho religioso como positivo, en cuanto que éste contribuye al desarrollo integral de la persona $\gg^{58}$.

En cualquier caso, el «Estado actúa ante el factor religioso sólo como Estado o, lo que es lo mismo, laicamente y no como sujeto de fe, cuando considera lo religioso exclusivamente como factor social específico y procede en consecuencia». Lo religioso sería «entendido y tratado exclusivamente como factor social que forma parte también del bien común ${ }^{59}$. Habrá sin embargo quien vuelva a mostrarse reticente ante este argumento, si se interpreta «en el sentido de que, sólo el fenómeno religioso forma parte del bien común», y en

giosos no supone una valoración diferente a la que merecen los demás derechos fundamentales»; al menos si por diferente entendemos específica o peculiar. Resulta menos discutible admitir que en «la base de la cooperación existe siempre una valoración positiva de la actividad de las confesiones por parte del Estado» cfr. FERNÁNDEZ CORONADO, A., «Cooperación con las confesiones religiosas», en Enciclopedia furídica Básica, vol. I, Civitas, Madrid, 1995, p. 1710.

56 La misma STC 46/2001, al apuntar el «contexto constitucional» del registro de entidades religiosas, resalta «que el legislador otorga a las confesiones o comunidades inscritas en el Registro una especial protección jurídica» (F. 7).

57 La «laicidad positiva, en contraposición con la de exclusión o el laicismo, es la única que considera que la religión es importante para los ciudadanos. A las democracias liberales no les compete decidir si efectivamente la religión es algo importante, sino solo que los ciudadanos así lo ven, lo cual a su vez implica que no es algo que pueda ser privatizado, como si la esfera pública debiera quedar libre de toda intromisión religiosa» cfr. GAMPER, D. (2016), pp. 26 y 63. MANTECÓN, J. (2015), p. 39, apunta por su parte: «Lo que impera nuestra Constitución es que los Poderes públicos deben de adoptar una postura activa y positiva hacia las Confesiones. No otra cosa significa cooperar».

58 Olmos, M.E. (2006), p. 421. Para Porras, J.Ma . (2006), p. 123, se pretende «evitar un entendimiento excesivamente riguroso del principio de laicidad, más propio del Estado liberal decimonónico, que pueda dar lugar a una actitud estatal indiferente, pasiva o, incluso, contraria a la plena realización del derecho fundamental»; mientras que «al requerir su consideración, se está fundamentando una ulterior actuación de los poderes públicos, que conduce a valorarlo positivamente, en tanto que expresión de un interés jurídico protegido, de relevancia constitucional».

59 Viladrich, P.J. y Ferrer, J. (1996), pp.133 y 136. 
consecuencia «las creencias religiosas merecen una mayor protección que las no religiosas ${ }^{60}$.

Cierta querencia hacia posturas laicistas no deja de resultar lógica, ya que la ausencia de sensibilidad para lo sobrenatural inclina a interpretar toda influencia social en clave de poder. Se olvida así la distinción clásica entre potestas y auctoritas; mientras la primera implica una habilitación para ejercer acciones coercitivas, la segunda es fruto de la positiva acogida social a unas propuestas como fruto del prestigio personal o la autoridad moral. «Poder alude siempre a superioridad y dominación e implica siempre la existencia de alguien subordinado y que obedece. El poder religioso domina sobre el fiel; el secular sobre el súbdito ${ }^{61}$. Partiendo de esta perspectiva, una iglesia, sobre todo cuando es de modo acusado socialmente mayoritaria, puede aparecer como una amenaza para quien aspira a imponer totalmente su poder.

Aun sin llegar a tales extremos, la laicidad positiva suscitará dudas entre quienes suscriben la propuesta laicista esgrimiendo una presunta neutralidad, que lleva a recelar de la influencia eclesiástica ${ }^{62}$. Aun sin llegar a la hostilidad, la laicidad positiva resulta así de difícil digestión. «La laicidad del Estado supone que éste no deba establecer una valoración favorable ni desfavorable de

60 Para CASTRO, A. (2003), p. 14, esta interpretación «no sería compatible con los valores constitucionales, el primero de los cuales es la libertad cuyo ejercicio conduce a un mosaico de códigos valorativos, todos ellos merecedores de una valoración positiva». No faltará, sin embargo, quien sugiera motivos de posible tratamiento peculiar: «Incluso aunque ya no sea posible mantener en términos históricos la tesis de Jellinek acerca de la génesis de los derechos humanos a partir de la noción de libertad religiosa, existe, no obstante, un nexo conceptual entre una fundamentación universalista del derecho fundamental de la libertad religiosa, por un lado, y el fundamento normativo de un Estado constitucional, esto es, la democracia y los derechos humanos, por el otro», en Habermas, J. (2003), p. 5. En esa misma línea NúÑEZ LADEVEZE, L.: en «la evaluación de la tradición ilustrada europea la libertad de opinión es históricamente», a su juicio, «un corolario de la 'libertad religiosa'. Se llega al pronunciamiento de un principio general de libertad de expresión a partir de la previa aceptación histórica del principio de libertad religiosa», en «Tensión entre la libertad religiosa y otros derechos fundamentales. Perspectiva occidental a la dimensión de los derechos», Cuadernos de Derecho fudicial, XIX (2006), p. 14.

$61 \ll$ Cuando se ve en el dominado una realidad indivisible que no permite distinguir entre el fiel y el súbdito la tensión y el choque entre poderes es inevitable: ambos querrán estar por encima del otro», en LlamaZares, D. (2003), p. 200.

62 Para Díaz-Salazar Martín, R., «las instituciones y fuerzas políticas, aunque asumen la personalidad jurídica pública de la Iglesia, tienden en la práctica a concebir a dicha institución como un grupo privado y, por eso, cuando la Iglesia realiza una intervención pública en campos no estrictamente religiosos, se considera que esta institución realiza una interferencia indebida en la vida pública», en «Política y religión en la España contemporánea» Revista Española de Investigaciones sociológicas (52) (1990), p. 72. 
ciertas creencias, o incluso del propio hecho de creer en Dios (aspectos que en todo caso le toca valorar a la propia religión, a la filosofía, a la psicología o alguna otra dimensión del saber humano)» ${ }^{63}$. En todo caso, «la percepción que el Estado formula del hecho religioso es indispensable para determinar el verdadero cariz de neutralidad con que se va a presentar»; «mientras que en la laicidad existe una valoración positiva, o bien social y enteramente neutral del hecho religioso, en el laicismo, en cambio, su valoración inicial es eminentemente privatista y habitualmente negativa»; lo que obliga a distinguir entre «un Estado neutral»y uno «neutralizador» ${ }^{64}$.

La crítica respecto a los defensores de una solo presunta neutralidad se ha generalizado desde autores libres de toda sospecha. La llamada Plataforma por una Sociedad Laica ${ }^{65}$, por ejemplo, constituiría «un buen ejemplo de lo que podríamos denominar laicismo neutralizador del factor religioso» ${ }^{66}$. Se llegó incluso a diagnosticar «una transposición de la religiosidad popular extraeclesiástica hacia un tipo de lo que podríamos definir religiosidad laica roja, que implicaría una 'religiosización de políticas ateas' con aires de 'sacralización'» ${ }^{67}$.

Se han estudiado en España con especial detenimiento actitudes dudosamente neutrales en el ámbito socialista, que se han atribuido a la concepción

63 Marciani Burgos, B., «Los dilemas de la laicidad positiva: un análisis a partir del caso peruano», Doxa (38) (2015), p. 260.

64 Mureddu GONZÁLEZ, M.A. «Laicidad y laicismo: la conceptualización política y normativa de lo religioso», Anuario de Derecho Eclesiástico del Estado, XXXII (2016), pp. 634-635.

65 No muy alejado de ella se mostraba «El Intergrupo por el Laicismo del Congreso, creado el 10 de noviembre de 2004, del que forman parte todos los grupos parlamentarios excepto el $\mathrm{PP} \gg$; concebía «la religiosidad como una opción privada» y pretendía «contrarrestar desde la sociedad civil la creciente implicación de la Iglesia católica en la vida política», manteniendo «contactos con entidades sociales que trabajan por el laicismo, como Ateos de Cataluña» cfr. LóPEZ-SIDRO LÓPEZ, A., «La consideración de las creencias religiosas por los poderes públicos: la referencia del artículo 16.3 de la Constitución», Revista General de Derecho Canónico y Derecho Eclesiástico del Estado (8) (2005), p. 10.

66 Nos «encontramos en la historia de los últimos siglos y en la actualidad una laicidad excluyente de la religión en el espacio público. Su concepción de la libertad religiosa no va mucho más allá de la libertad de culto. Propugna una privatización forzada de la religión y, en más de un caso, es una forma más o menos encubierta de ateísmo militante. Frente a este modelo, ha surgido en los últimos decenios una laicidad inclusiva de religiones ilustradas y de liberación, pues constituyen culturas cívicas que enriquecen la convivencia y los proyectos sociales, políticos y económicos que dan primacía a la emancipación de los dominados y empobrecidos» cfr. Díaz SALAZAR, R. (2010), pp. 65 y 78.

67 «En muchos sectores, el anarquismo, el socialismo y el comunismo fueron experimentados como una nueva religión. La misma violencia simbólica y sangrienta contra realidades religiosas estuvo presidida por otra religiosidad sustitutoria», en DíAZ SALAZAR, R. (1990), p. 67. 
dominante en «la cultura socialista, para la cual la religión es un asunto privado». Esto contrasta con la apreciación sociológica de «la gran base electoral católica del PSOE; según los estudios electorales existentes, el PSOE depende totalmente del voto católico, y el porcentaje de este voto es mucho mayor que el perteneciente al grupo de los indiferentes, agnósticos y ateos. Incluso el grupo de 'católicos practicantes' es mayor que el de 'indiferentes, agnósticos y ateos' en los votantes socialistas» ${ }^{68}$.

No es extraño que se haya dictaminado que no se puede hablar de neutralidad estatal cuando «toma como propia una ideología, una concepción de la existencia, que pretende imponer desde el poder desconociendo los derechos de las minorías, e incluso, en no pocas ocasiones, de la misma mayoría ${ }^{69}$. Más bien parece «evidente que este concepto de laicidad, que hoy es más propio denominar laicista para distinguirlo del sentido moderno, deriva en una singular religiofobia $\gg^{70}$.

La presión de una presunta neutralidad así entendida genera un fenómeno que he calificado de laicismo autoasumido; empuja a los creyentes a recluirse en lo privado, ante el temor de ser acusados -por ser mayoría- de imponer sus convicciones a los demás ${ }^{71}$. El católico español acaba así encontrándose en

68 Díaz SALAZAR, R. (1990), pp. 75, 71 y 76, considera que la primera apreciación «posee grandes dosis de ingenuidad sociológica y no resiste la crítica sociológica». Reconoce que «existe una importante influencia de la religión en el voto político» y que se «llega incluso a afirmar que la variable religiosa es más decisiva que la variable clase social». LÓPEZ-SIDRo LóPEZ, A. (2005), p. 11, evoca «los trabajos del Consejo de Libertades Públicas del PSOE, constituido el 4 de noviembre de 2004, dirigidos a 'garantizar la aconfesionalidad y laicidad del Estado', conformando un Estatuto de Laicidad con la colaboración de los Ministerios de Justicia e Interior»; recoge al respecto noticia de prensa sobre presuntas propuestas de incluso «suprimir las procesiones de Semana Santa».

69 Distinto es el asunto cuando la «neutralidad estatal significa su radical indiferencia hacia toda valoración religiosa del hecho religioso, pero no su indiferencia hacia una estimación política basada, no en creencias objetivas religiosas o morales, sino en la efectiva demanda social». En tal caso, «cuando el Estado proceda a la remoción de obstáculos o a la concesión de facilidades para las actividades religiosas no estará, en el fondo, dialogando con las confesiones ni defendiendo sus intereses; estará dialogando con la sociedad que es el verdadero soporte humano de toda Iglesia», en FERNÁNDEZ-MIRANDA, A. (1978), pp. 12-13 y 18.

70 Motilla, A. (2008), p. 71. De ahí que se dictamine que se ha «acuñado la expresión 'laicismo' para designar a esta versión sectaria y desnaturalizada de la laicidad. En el Estado laicista, la 'neutralidad' oficial encubre una situación de efectiva «confesionalidad inversa» cfr. CONTRERAS, F.J. (2015), p. 60.

71 «Flagelarnos por estar en algún lugar, por disponer de un horizonte, por enfocar el mundo desde una perspectiva es el último descubrimiento del criticismo masoquista occidental». «A mi entender, eso es lo que hace del laicismo un sentimiento demoledor». Esta «forma de argumen- 
una situación embarazosa cada vez que intenta «terciar en el debate social»; aunque utilice «argumentos rigurosamente laicos» y no invoque «en ningún momento a Dios», sus «tesis serán tachadas sistemáticamente de confesionales». Por el contrario, sus adversarios «creen no tener creencias»; el «ateo típico considera la inexistencia de Dios, la ausencia de cualquier propósito o plan en la creación, la aniquilación de la conciencia en la muerte física, etc., no como opiniones filosóficas suyas, sino como la expresión del 'sentido común' neutral, universal, accesible a todos (salvo a esos pintorescos creyentes religiosos, instalados todavía en el pensamiento mágico). El ateo medio cree no creer nada: está convencido de que él no cree, sino que sabe. En la medida en que considera sus tesis materialistas como conocimientos (y no como creencias), no se siente obligado a hacer abstracción de ellas cuando participa en debates morales o jurídicos-políticos» ${ }^{72}$.

Una buena cura de urgencia ofrece la propuesta del Habermas postsecular, en su contraposición de naturalismo y religión ${ }^{73}$. De ahí que se señalara que sería conveniente «explorar las posibilidades de la propuesta habermasiana en nuestro país para mejorar la convivencia y el diálogo entre laicistas que no son religiosos y católicos»; parecerá, en consecuencia, interesante la aparición de «una laicidad de reconocimiento del rol positivo que ejercen las comunidades

tar del criticismo relativista y, a veces, del multiculturalismo, disimula que es una posición tan céntrica como las que critica, que trata de estar por encima de todos mientras aparenta no estar en ninguna parte, que se presenta inmune a la crítica que hace a los demás como si el crítico que critica pudiera pensar sin posición, sin centro, sin lugar o sin identidad». «Como si fuera posible que alguien pudiera estar en ninguna parte mientras discute con otro» cfr. NúÑEZ, L. (2006), pp. 10 y 9 .

72 Como respuesta, «Los católicos deberíamos, pues, recusar estas falsas neutralidades y reclamar sin ambages nuestro derecho a ser laicos: nuestro derecho a participar en el debate democrático, en estricto pie de igualdad con los ciudadanos de otras convicciones» cfr. CONTRERAS, F. J. (2015), pp. 62 y 64. Parece obvio que «la tolerancia de creencias religiosas en sociedades laicas supone reconocer la posibilidad de que tales creencias sean consideradas en el debate público en igualdad de condiciones que cualesquiera otras creencias, por ejemplo, de tipo político» cfr. MarciLla, G. M. (2015), p. 1874. Sobre todo si, más allá de toda tolerancia, se está ejerciendo un derecho fundamental inequívocamente político; no se trata que se me tolere como creyente sino de que se me reconozca como ciudadano.

73 Habermas, J., Entre naturalismo y religión, Paidós, Barcelona, 2006. De ello traté en «Macht oder Vernunft. Die Religion im öffentlichen Bereich (Zugleich ein Dialog über Habermas' postsäkulare Gesellschaft)», Workshop über «Sterbehilfe aus ethischer und rechtlicher Sicht / Die Religion im öffentlichen Bereich in XXV Weltkongress der Internationalen Vereinigung für Rechts -und Sozialphilosophie, Frankfurt a. M. August 2011»; en castellano en Anales de la Real Academia de Ciencias Morales y Políticas, 2012 (LXIV-89), pp. 147-156. 
religiosas en la vida pública y el establecimiento de una política estatal de cooperación con las mismas» ${ }^{74}$.

La inclusión de la cooperación en la laicidad positiva ha llevado por otra parte, a involucrar al artículo 9.2 CE en la argumentación. Parece lógico que ello ocurra, tras el paso de la religiosa como libertad negativa, que solo exige no injerencia, a convertirse en libertad positiva con pretensiones prestacionales. Se evoca con facilidad un artículo según el cual, como es sabido, corresponde «a los poderes públicos promover las condiciones para que la libertad y la igualdad del individuo y de los grupos en que se integran sean reales y efectivas; remover los obstáculos que impidan o dificulten su plenitud y facilitar la participación de todos los ciudadanos en la vida política, económica, cultural y social». La propia STC 46/2001 lo ha hecho con generosidad ${ }^{75}$, no consciente quizá de posibles derivas interpretativas.

Se comprende pues que haya quien afirme que la «igualdad material aparece contenida en el art. 9.2 de la CE»; «su logro constituye el contenido del mandato dirigido a los poderes públicos que con su intervención deben hacer posible el ejercicio de la libertad religiosa a todas las personas. Es aquí donde encuentra su fundamento normativo la llamada neutralidad o laicidad positiva ${ }^{76}$. Con ello se minusvaloran sin embargo aspectos nada irrelevantes. No concedo mayor importancia a que el citado artículo fuera en su día acogido con cierto recelo, dado que su procedencia italiana llevó a vincularlo con el uso alternativo del

74 «Un filósofo ateo como Habermas es muy contundente en este tema. Según él, la fe religiosa es razonable y debe ser tomada en serio desde una teoría del conocimiento. Las religiones tienen contenido racional y forman parte de la historia de la razón» cfr. DíAz SALAZAR, R. (2010), pp. 68,72 y 73 .

75 Señala, por ejemplo, que el artículo $16 \mathrm{CE}$ «hunde sus raíces en el art. 9.2 del texto constitucional, conforme al cual se impone a los poderes públicos una directriz de actuación favorecedora de la libertad del individuo y de los grupos en que se integra, y creadora de las adecuadas condiciones para que tales libertades sean reales y efectivas, y no meros enunciados carentes de real contenido» (F.7). Por otra parte, plantea que la inscripción en el registro está orientada «a facilitar el ejercicio colectivo de su derecho a la libertad religiosa, en tanto que instrumento ordenado a 'remover los obstáculos', y a 'promover las condiciones para que la libertad y la igualdad del individuo y de los grupos en que se integra sean reales y efectivos' ex art. 9.2 CE». Precisamente fundamentará la estimación del amparo a la llamada Iglesia de la Unificación en que «la indebida denegación por la Administración responsable del Registro de la inscripción solicitada, viene a constituirse en un injustificado obstáculo que menoscaba el ejercicio, en plenitud, del derecho fundamental de libertad religiosa» (F. 9).

76 Castro, A. (2003), p. 32. Tampoco Molano, E. (1986), p. 253, encuentra problema para interpretar inocentemente que el artículo $16.3 \mathrm{CE}$ reduplica «lo que ya genéricamente establece el artículo 9.2». 
derecho, entonces de moda. Más significativo sería que emparentaba a la laicidad positiva con la norteamericana affirmative action y su búsqueda de paridad en el trato a minorías marginadas. Su juego, de notable impacto en nuestra jurisprudencia constitucional sobre discriminación por razón de $\operatorname{sexo}^{77}$, no tiene nada que ver con lo sugerido a los mismos poderes públicos en el artículo 16.3 CE.

No faltará en consecuencia quien se extravíe por esa equivocada paritaria vía. El problema residiría «en cifrar el sentido y alcance de esta dimensión positiva de la libertad religiosa, de manera que la colaboración material de los poderes públicos se desarrolle de una manera paritaria en el fomento de las libertades públicas». Sin embargo, «el hecho evidente es que esta dimensión positiva de la libertad religiosa tiene en la Constitución un expreso y exclusivo cauce de desarrollo y promoción -las relaciones de cooperación del artículo 16,3-, que no aparece en la regulación de otras libertades, a pesar de que el ejercicio de las mismas demandan la necesidad de la intervención material del Estado» ${ }^{78}$. Tan cierto como que olvidarlo llevará a malentender la articulación de la cooperación imperada por su artículo 16.3 CE, como habrá ocasión de comprobar.

\section{CoOperación. La STC 34/2011, DE 28 DE MARZO}

Ha cambiado, por tanto, el concepto de laicidad apartándose de la connotación negativa decimonónica de impronta francesa ${ }^{79}$. La laicidad positiva inseparable de la cooperación en modo alguno puede servirle de límite, aunque haya quien se mantenga reticente ${ }^{80}$. El balance, sin embargo, parece cla-

77 Convirtió de hecho al artículo 9.2 en imprevista vía de acceso al recurso de amparo, enlazando con el artículo 14 CE. Con ello la discriminación por razón de sexo dejó de contemplarse con ojos neutros, que descubrían a los viudos como sus presuntas principales víctimas, para centrarse en la exigencia de paridad de trato para la mujer. Lo puse de relieve en Discriminación por razón de sexo. Valores, principios y normas en la jurisprudencia constitucional española, Centro de Estudios Políticos y Constitucionales, Madrid, 1999.

78 Soriano, R. (1986), p.100.

79 Están en juego «los principios de laicidad del Estado y cooperación con las Confesiones, que pueden ser considerados como contradictorios, dependiendo de cuál sea el significado que se atribuya a cada uno de ellos» cfr. FERRER, J. (1987), p. 239.

80 LlamazarEs, D. (2003), p. 216, se erige en intérprete de la STC 46/2001 en términos sorprendentes. Sus tres conceptos claves serían neutralidad, separación y cooperación, pero ésta tendría «como límite la laicidad en sus dos componentes: la neutralidad y la separación». De la neutralidad tendremos oportunidad de ocuparnos, pero la palabra separación ni siquiera figura en la amplia fundamentación de la sentencia. MORENO, M.M. (2006), p.78, anotará: en «las aportaciones doctrinales aparecen en muy pocas ocasiones los términos de neutralidad y separación». 
ro. «La Constitución valora positivamente el ejercicio de la libertad religiosa como valora positivamente el ejercicio de cualquiera otra libertad. Pero en el caso específico de la libertad religiosa no lo hace sólo de un modo genérico, sino que dedica una parte de su normativa constitucional acerca de esta libertad a ordenar expresamente una cooperación por parte de los poderes públicos» ${ }^{81}$. Sin grandes entusiasmos se constatará que, aunque parezca complejo, nos encontramos ante «un mandato a los poderes públicos: el de tener en cuenta las creencias religiosas de la sociedad española. No se trata de algo potestativo, sino de un verdadero mandato legal asentado sobre un supuesto dato sociológico que la Constitución incorpora» ${ }^{82}$.

Se ha señalado como significativo que «el principio de cooperación apareciera ya, prácticamente con la misma redacción que la vigente, en el borrador de la Constitución elaborado en marzo de 1978. Dicho texto fue superando, inalterado, las distintas etapas por las que pasó el texto constitucional» ${ }^{83}$. Todo ello acabará considerándose constitucionalmente compatible con los afanes de neutralidad. «Es precisamente el elemento cambiante de la neutralidad el que ha transformado el sentido de la laicidad de negativa a positiva» ${ }^{84}$.

Ilustrativa al respecto resultará -siguiendo la estela de la resolución del Tribunal Europeo de Derechos Humanos en la caso Lautsi contra Italia ${ }^{85}$ - la STC 34/2011. La respuesta al recurso de amparo de un abogado que considera que su colegio profesional sevillano vulnera objetivamente la Constitución $\mathrm{y}$, de resultas, lesiona subjetivamente su derecho como no creyente al tratarle desigualmente; en sus estatutos, tras declararse «aconfesional», reconoce que

81 Molano, E. (1986), p. 253. También Barrero, A. (2015), p. 40, constata el cambio experimentado: «Mientras que la laicidad tiene un contenido eminentemente negativo o esencialmente limitador de la acción estatal, la cooperación presenta un contenido positivo o promotor de la libertad religiosa». Por su parte, ConTreras Mazario, J.M ${ }^{a}$., apunta que la libertad religiosa «en la actualidad no puede configurarse únicamente como un derecho exclusivamente de naturaleza negativa por lo que respecta a su garantía, y ello a pesar de estar integrado dentro de los derechos de primera generación», en «Laicidad y derechos de las minorías», en Libertad de conciencia y laicidad en las instituciones y servicios públicos, Dykinson, Madrid, 2005, p. 144.

82 Suárez Pertierra, G. (2002), p. 332.

83 Mantecon, J. (2015), p. 38. Para Suárez Pertierra, G. (2002), p. 333, por el contrario, la «redacción del precepto de nuevo responde a presiones externas. La idea de cooperación no se encuentra en los primeros textos de la Constitución». Debe referirse a propuestas informales, porque ya figuraba en el Anteproyecto de 5 de enero de 1978 cfr. Constitución Española. Trabajos parlamentarios, t. I, p. [10].

84 Castro, A. (2003), p. 31.

85 La hemos comentado en «La Europa desintegrada: Lautsi contra Lautsi», incluido en Religión, racionalidad y política, Comares, Granada, 2013, pp. 157-162. 
«por secular tradición tiene por Patrona a la Santísima Virgen María, en el Misterio de su Concepción Inmaculada $»^{86}$.

El Tribunal Constitucional recordará al respecto que en «su dimensión objetiva, la libertad religiosa comporta una doble exigencia, a que se refiere el art. 16.3 CE: primero, la de neutralidad de los poderes públicos, ínsita en la aconfesionalidad del Estado; segundo, el mantenimiento de relaciones de cooperación de los poderes públicos con las diversas confesiones ${ }^{87}$.

En consecuencia, el Tribunal considerará obligado «dilucidar dos aspectos: primero, si el Colegio de Abogados de Sevilla está constitucionalmente obligado a la neutralidad religiosa y, en caso de ser así, si la norma estatutaria controvertida tiene una significación incompatible con ese deber» Admite que a la primera cuestión «ha de responderse afirmativamente», ya que «todas las instituciones públicas han de ser ideológicamente neutrales» $\mathrm{y} \ll$ los colegios profesionales» son «corporaciones de derecho público» ${ }^{88}$.

Entra en juego a continuación la dimensión comunitaria del problema. Ya en los primeros compases del artículo $16 \mathrm{CE}$ se descarta una incidencia meramente individual del derecho de libertad religiosa y de culto, pues se lo reconoce no solo al ciudadano sino también a «las comunidades ${ }^{89}$; de hecho dos epígrafes más abajo serán las confesiones religiosas las protagonistas.

El Tribunal se adentra en la cuestión constatando que «es propio de todo ente o institución adoptar signos de identidad que contribuyan a dotarle de un carácter integrador ad intra y recognocible ad extra, tales como la denominación -elemento de individualización por excelencia-», pero también «los emblemas, escudos, banderas, himnos, alegorías, divisas, lemas, conmemoraciones y otros», «entre los que pueden encontrarse, eventualmente, los patronazgos, en su origen propios de aquellas confesiones cristianas que creen en la intercesión de los santos y a cuya mediación se acogen los miembros de un

86 Considera que con ello «se aparta de la neutralidad que en materia religiosa es exigible a toda institución de Derecho público» e incurre en «infracción del derecho a la igualdad (art. $14 \mathrm{CE}$ ), en la medida en que se priman las creencias religiosas de un determinado grupo en detrimento de quienes mantienen otras o carecen de ellas», en STC 34/2011, FF. 1 y 3.

87 STC 34/2011, F. 3.

88 STC 34/2011, F. 4.

$89 \ll$ Salvo muy escasas excepciones, las religiones son, ante todo y sobre todo, comunitarias». «La tendencia universal dominante es la dimensión pública de las religiones y en las sociedades secularizadas estamos experimentando una desprivatización de las religiones» cfr. DíAz SALAZAR, R., «Modernización, religiones y laicidad en el sistema-mundo», Sistema (239) (2015), pp. 68. 
determinado colectivo $»^{90}$. Por si fuera poco, «cuando una religión es mayoritaria en una sociedad sus símbolos comparten la historia política y cultural de ésta, lo que origina que no pocos elementos representativos de los entes territoriales, corporaciones e instituciones públicas tengan una connotación religiosa $\gg^{91}$.

Enlaza así con facilidad con la doctrina sentada en Estrasburgo con ocasión del caso Lautsi contra Italia. En este una ciudadana de origen finlandés reclama la retirada de los crucifijos de las escuelas públicas por considerar tal presencia traumática para su retoño. Tras verse amparada unánimemente por el veredicto de una Sala, el fallo cambiará de signo cuando quien juzga en plenario es la Gran Sala, que decide por amplia mayoría lo contrario ${ }^{92}$. Considera en efecto que «la percepción subjetiva del reclamante por sí sola no basta para caracterizar una violación del derecho invocado». El Constitucional español abundará en ello: «todo signo identitario es el resultado de una convención social y tiene sentido en tanto se lo da el consenso colectivo; por tanto, no resulta suficiente que quien pida su supresión le atribuya un significado religioso incompatible con el deber de neutralidad religiosa, ya que sobre la valoración individual y subjetiva de su significado debe prevalecer la comúnmente aceptada, pues lo contrario supondría vaciar de contenido el sentido de los símbolos, que siempre es social» ${ }^{93}$.

Por otra parte, apuntará que «debemos tomar en consideración no tanto el origen del signo o símbolo como su percepción en el tiempo presente, pues en una sociedad en la que se ha producido un evidente proceso de se-

90 Los símbolos pasan a jugar un papel relevante. «Enriquecido con el transcurso del tiempo, el símbolo acumula toda la carga histórica de una comunidad», cumpliendo «una función integradora y promueven una respuesta socioemocional, contribuyendo a la formación y mantenimiento de la conciencia comunitaria»; a la vez que, como «expresión externa de la peculiaridad de esa Comunidad, adquiere una cierta autonomía respecto de las significaciones simbolizadas, con las que es identificada», en STC 34/2011, F. 4.

91 STC 34/2011, F. 4.

92 La STC 34/2011 hace también propio el argumento de Estrasburgo sobre «la menor potencialidad para incidir sobre la neutralidad religiosa del Estado de los símbolos o elementos de identidad esencialmente pasivos frente a otras actuaciones con capacidad para repercutir sobre la conciencia de las personas, como son los discursos didácticos o la participación en actividades religiosas» (F. 4). De ahí que descarte la pretensión del recurrente de que «la simple designación de la Patrona supone, como mínimo, la imploración de su protección y el sometimiento a la misma, regulándose algo que pertenece a la esfera de la más estricta intimidad de cada uno de los miembros de la corporación» (F. 5).

93 STC 34/2011, F. 4. 
cularización es indudable que muchos símbolos religiosos han pasado a ser, según el contexto concreto del caso, predominantemente culturales aunque esto no excluya que para los creyentes siga operando su significado religioso». Se apoyará en la STC 19/1985, de 13 de febrero, que lo ejemplifica en «el descanso semanal»; es hoy «una institución secular y laboral, que si comprende el domingo como regla general» es «porque este día de la semana es el consagrado por la tradición» $(\mathrm{F}, 4)^{94}$. El argumento no resulta inmune a la crítica ${ }^{95}$.

La única salvedad, puesta ya de relieve en sentencia anterior ${ }^{96}$, es que «se garantice la libertad de cada miembro para decidir en conciencia si desea o no tomar parte en actos de esa naturaleza»; nada de esto ha ocurrido en el presente caso, en el que ni aun siquiera a efectos dialécticos ha sostenido el recurrente que venga obligado a participar en eventuales actos de contenido religioso en los que el Colegio de Abogados de Sevilla pudiera hacerse presente.

La fundamentación acude finalmente a un argumento netamente civil. «La posibilidad de que la corporación asuma signos de identidad» que fueran «en su origen propios de una u otra confesión o de ninguna, es algo que sólo a la corporación corresponde decidir democráticamente (art. $36 \mathrm{CE}$ )». Lo hará «considerando cuáles son las señas de identidad que de forma más oportuna o conveniente cumplen la función integradora o representativa buscada»; o sea la que «lisa y llanamente, satisface o responde mejor a las sensibilidades y

94 La STC 34/2011, F. 4, considera que los estatutos sevillanos contienen «dos proposiciones aparentemente antitéticas - «el Ilustre Colegio de Abogados de Sevilla es aconfesional» y «tiene por Patrona a la Santísima Virgen María, en el Misterio de su Concepción Inmaculada»- cuya debida compresión se obtiene a partir de las palabras que les sirven de unión: «si bien por secular tradición»; «precisamente con el propósito de evitar interpretaciones como la que sostiene el recurrente».

95 Crítico al respecto Salazar, O. (2015), pp. 171 y 164: «el TC opta por, en nombre de la tradición convertida en cultura, diluir la exigencia de neutralidad religiosa y prorrogar una confesionalidad simbólica o identitaria». La «tradición se impone sobre la aconfesionalidad que, en el caso del Colegio de abogados sevillano, pierde consistencia ante una mera constatación de las reales creencias religiosas de una parte de la sociedad sevillana a lo largo de la historia».

96 La STC 177/1996, de 11 de noviembre, F. 10, que resaltó que «el art. 16 CE no impide a las Fuerzas Armadas la celebración de festividades religiosas o, más propiamente dicho, la participación en ceremonias de esa naturaleza»; con ocasión de una parada militar en Paterna (Valencia) en honor de la Virgen de los Desamparados. Ahora se insistirá en que «fácilmente se comprende que cuando una tradición religiosa se encuentra integrada en el conjunto del tejido social de un determinado colectivo, no cabe sostener que a través de ella los poderes públicos pretendan transmitir un respaldo o adherencia a postulados religiosos», en STC 34/2011, F. 4. 
preferencias de diversa índole de quienes con su voto mayoritario contribuyan a la aprobación de los elementos representativos de la institución ${ }^{97}$.

Todo el razonamiento invita a entender que el «tener en cuenta las creencias» del artículo 16.3 remite a un trasfondo sociológico, que no dejará de suscitar nuevo debate. Se apuntará, por ejemplo, que «en Estados como la República Federal de Alemania» se considera que «el único criterio que puede adoptar un Estado neutral en materia religiosa respecto de las confesiones es el criterio sociológico, renunciando a juzgar su status jurídico según criterios teológicos de la seriedad o la dignidad de su doctrina, entendiéndose que queda así suprimido el carácter privilegiado del estatuto de las grandes iglesias, porque cualquier otra confesión tiene acceso a él» ${ }^{98}$. Habrá, sin embargo, quien sugiera que nuestro articulado constitucional estaría informado por un «principio de confesionalidad histórico sociológica, lo que, evidentemente, pone en guardia sobre su constitucionalidad $»^{99}$.

$\mathrm{Si}$ antes se pretendía remitir el trato con las confesiones a la legalidad general asociativa, ahora se propondrá una equiparación «legal de las confesiones religiosas españolas en el orden jurídico, fiscal e institucional», «con el objetivo de que la Iglesia católica deje ya de ser el modelo único a seguir y se convierta en una de las formas de un modelo legal único para todas las iglesias» ${ }^{100}$.

Lo que queda constitucionalmente fuera de discusión es que la cooperación no se podrá mantener necesariamente con las más de mil entidades religiosas inscritas; se «impone a los poderes públicos un mandato de coope-

97 Se argumenta en este caso cómo en «la STC 130/1991, de 6 de junio, en relación con la presencia de la imagen de la Virgen de la Sapiencia en el escudo de la Universidad de Valencia», se aprecia que «resultaba compatible con la aconfesionalidad proclamada en nuestra Constitución, tanto la decisión del claustro universitario de proceder a su supresión como la que hubiera supuesto su mantenimiento», en STC 34/2011, FF. 6 y 4.

98 Roca FernandeZ, $M^{\mathrm{a}}$.J., «Laicidad del Estado y garantías en el ejercicio de la libertad: dos caras de la misma moneda», El Cronista del Estado Social y Democrático de Derecho (3) (2009), p. 50.

99 LlamaZares, D. (2003), pp. 215-216. En otros casos tal cooperación se considera irrelevante, al tratarse de confesiones con «peso minúsculo -si tienen alguno- en la vida colectiva del conjunto de los españoles, dada la exigüidad del número de sus miembros y del carácter étnico-religioso de las comunidades hebrea y musulmana, que las excluye de toda pretensión de influir, como tales, en la vida pública española» cfr. PUENTE OJEA, G. (2007), p. 339.

100 Soriano, R. (1986), p. 157. La «cooperación no tiene por qué discurrir, más que excepcionalmente, a través de la vía de los acuerdos, debiendo materializarse, preferentemente, por medio de leyes que, deduciendo normas generales, aplicables a todos, armonicen el tratamiento que los poderes públicos le han de dispensar, facultativamente, a las confesiones que se lo demanden» cfr. PORRAS, J.Mª. (2006), p. 221. 
ración en relación con aquéllas que, estando ya inscritas en el Registro, por su ámbito y número de creyentes hayan alcanzado notorio arraigo en España ${ }^{101}$. Habrá quien considere que «se pretende utilizar a estas confesiones minoritarias como coartada para disimular la situación de privilegio de la Iglesia católica, extendiendo a ellas esos mismos privilegios, so pretexto del principio de igualdad» ${ }^{102}$.

La verdad es que no tiene mucho sentido tachar de confesional, de modo individual o múltiple, a lo que es el mero resultado de tener en cuenta las creencias de una sociedad plural y diversa. Intentar reflejarla en una normativa genérica difícilmente podría traducir esa realidad social adecuadamente. Resulta significativo al respecto que se haya criticado precisamente la escasa variedad existente en el contenido de las leyes de 1992 destinadas a regular la cooperación con entidades religiosas tan dispares como las evangélicas, judías e islámicas ${ }^{103}$. Los críticos, sin embargo, no parecen animados a tenerlo en cuenta: el «con-

${ }^{101} \mathrm{La}$ «Administración no debe arrogarse la función de juzgar el componente religioso de las entidades solicitantes del acceso al Registro, sino que debe limitarse a constatar que, atendidos sus estatutos, objetivos y fines, no son entidades de las excluidas» por la ley en STC 46/2001, FF. 6 y 10. LEGUINA VILLA, J., señala que «para que ese grupo sea 'público y sabido de todos' -que es el significado del adjetivo notorio»- «ha de alcanzar un número de miembros lo suficientemente importante como para que su existencia y su identidad diferenciada puedan ser conocidas por el ciudadano medio de nuestra sociedad y para que ese mismo ciudadano medio pueda sin dificultad tomar contacto con la entidad religiosa o tener, en su caso, acceso a sus templos o lugares de culto o reunión. De no ser así, el grupo podría eventualmente haber echado raíces en España, puede tener arraigo en nuestro país, pero carecería sin duda de notoriedad», en «Dos cuestiones en torno a la libertad religiosa: Control administrativo y concepto de notorio arraigo», Revista española de Derecho Administrativo (44) (1984), p. 691.

102 LlaMAZARES, D. (2013), p. 218, que toma como ejemplo «la financiación de sus profesores de religión, aun cuando en el acuerdo correspondiente del 92 no aparece ningún fundamento para que el Estado se considere obligado». Abunda en ello SALAZAR, O. (2015), p. 184, para el que las «excepciones a que dan lugar dichos acuerdos y los privilegios que suponen para una concreta confesión religiosa son incompatibles con un sistema basado en la conjunción de la igualdad y el pluralismo. A ello habría que sumar el efecto 'imitador' que han provocado en otras confesiones, con el consiguiente riesgo de consolidar un régimen 'pluriconfesional' en lugar de uno verdaderamente laico». Más drástico PuENTE OJEA, G. (2005), p. 3, «El Estado confesional de un solo credo religioso viola el sistema laicista de axiomas y postulados, pero el Estado pluriconfesional añade incluso un factor más dañino para la genuina libertad de conciencia, porque fortalece dramáticamente la dominación monopolista de la religiosidad».

${ }^{103}$ Martínez Torron, J., señala que «en los Acuerdos de 1992 el elenco temático se encuentra marcadamente inspirado en la normativa concordada con la Santa Sede», señalando «la absoluta uniformidad de las disposiciones de los tres acuerdos». «Se han acentuado excesivamente los rasgos comunes, hasta el extremo de suscitar serias dudas respecto al efectivo cumplimiento de la función que teóricamente les corresponde», en Separatismo y cooperación en los acuerdos del Estado con las minorías religiosas, Comares, Granada, 1994, pp. 134 y 135. 
cepto de 'notorio arraigo' ha tenido una serie de consecuencias que sólo con benevolencia pueden ser calificadas como 'nefastas'. Se trata de un concepto jurídico indeterminado, que introduce un enorme riesgo de discrecionalidad y arbitrariedad en la actuación de la Administración, y que incluso puede llegar a consolidar un modelo de Estado 'pluriconfesional' por la vía de los hechos» ${ }^{104}$.

\section{IGUALDAD CONSIGUIENTE}

Debemos aún ocuparnos de otro de los términos que, aun ajenos a la letra del artículo $16 \mathrm{CE}$, tienden a cobrar protagonismo en el debate sobre su alcance: la igualdad. Es bien sabido que tal principio figura ya en las primeras líneas de la Constitución española como uno de los «valores superiores de su ordenamiento jurídico»; acompañando por cierto, entre otros, al «pluralismo político». No deja de resultar llamativo que, equiparadas la libertad ideológica y religiosa en los primeros epígrafes del artículo $16 \mathrm{CE}$, a nadie se le ocurra reivindicar una igualdad ideológica, que sonaría incompatible con el pluralismo, mientras que la reclamación de una mayor igualdad religiosa se convierta en tópica desde determinadas perspectivas ${ }^{105}$. Tampoco se exige que los poderes públicos hayan de

104 Torres, A. (2004), pp. 596 y 597, que insiste en considerar «más útil optar por un modelo de derecho común, aplicable con carácter general a todas las confesiones religiosas, por el mero hecho de su inscripción registral». Insistirá en ello años más tarde en (2016), pp. 119-121, aun admitiendo que no cabe ignorar «el gran contenido garantista de la normativa española en materia de reconocimiento y protección de las minorías religiosas, ni minusvalorar el enorme paso adelante que supusieron los Acuerdos de 1992, pero ello no nos puede hacer olvidar la necesidad de planteamos la situación del resto de minorías religiosas que carecen de un Acuerdo de cooperación con el Estado, ni la conveniencia de tomar en consideración las indudables ventajas que presentaría la adopción de un régimen de derecho común a favor de todas las confesiones religiosas, con el que quedasen plenamente salvaguardados el principio de igualdad de todos los ciudadanos y la neutralidad en esta materia». De todas maneras, no oculta su ideal: «un modelo de derecho común de corte francés», «(que es uno de los modelos de laicidad más depurados del derecho comparado)». Habrá sin embargo quien opte por la enmienda a la totalidad: todos «pescan en las mismas aguas turbias del fetichismo, el irracionalismo y la emotividad». «Este clima malsano para el ejercicio de las libertades está en gran parte auspiciado o generado por los maléficos efectos del artículo 16.3 de la Constitución, el cual, tanto por su maliciosamente calculada redacción como por su viciosa aplicación, ha venido a sancionar y promover los privilegios de las religiones, olvidando que la cuestión no es qué religión debe contar con la protección de los poderes públicos, sino si todas las ideas o creencias van a disponer de iguales 'condiciones prácticas y efectivas' para su expresión y difusión» cfr. PUENTE OJEA, G. (2007), p. 195.

105 Soriano, R. (1986), pp. 97, 103 y 116, que se propone indagar «puntos de quiebra del principio de igualdad religiosa», titulará su empeño «El reconocimiento jurídico relevante del hecho 
igualar paritariamente sus ayudas a todos los partidos políticos y sindicatos, sin necesidad de que ello sea expresamente indicado por el texto constitucional, que sí explicita cómo ha de entenderse la cooperación con las confesiones: la consiguiente a «las creencias de la sociedad española», con la dimensión comunitaria ya apuntada ${ }^{106}$, a la que no falta respaldo en los tratados europeos ${ }^{107}$.

Una vez más resulta de interés el planteamiento de Rawls. Considera el juego de la igualdad como clave de la obligada neutralidad del Estado ante las diferentes doctrinas comprehensivas. Aun partiendo de una drástica separación entre poderes públicos y confesiones, ajena al modelo español, lo decisivo sería suscribir una «neutralidad de propósitos». Fiel a ella, «el Estado debe abstenerse de cualquier actividad que favorezca o promueva cualquier doctrina comprehensiva particular en detrimento de otras, o de prestar más asistencia a quienes la abracen», dando así paso a un dirigismo ideológico o religioso. Estima, en todo caso, imposible para la «estructura básica» deje de «tener importantes efectos e influencias en la selección de las doctrinas comprehensivas duraderas y capaces de ganar adeptos con el transcurso del tiempo; y es inútil tratar de compensar esos efectos e influencias, o incluso tratar de averiguar,

religioso como quiebra del principio de igualdad social». Según su diagnóstico, a «nivel constitucional, España se sitúa en un punto intermedio entre el separacionismo eclesiástico-estatal de Francia y Portugal y el estrecho colaboracionismo de Alemania e Italia, en el marco de una ostensible desigualdad religiosa».

106 Parece olvidarla FERNÁNDEZ CoRONADO, A. (1995), p. 1710, «La cooperación tiene su base en la igualdad en la libertad (arts. 14 y 16 CE), debe de llegar únicamente hasta donde sea necesario para hacer real y efectiva la igualdad de todos los ciudadanos en el ejercicio de la libertad religiosa (art. 9.2 CE) y no puede rebasar los límites que pudieran poner en peligro esa igualdad en la libertad. Se tratará, entonces, de una cooperación sólo en aquello que sea necesario para la realización individual de esos derechos». «Su límite se encuentra en la laicidad del Estado»; lo que ya descartamos y acaba reconociendo falto de fundamento: todo ello «resulta especialmente relevante si se tiene en cuenta que no existe mandato de igualdad constitucional para las confesiones de forma explícita en la Constitución (art. 14 CE)».

107 Para Navarro VALls, R., los «trazos comunes del modelo europeo sobre el factor religioso» suponen un «rechazo simultáneo del indiferentismo religioso y la teocracia». Detecta en ellos «una versión actualizada en clave laica del dualismo cristiano. Un modelo de cooperación formal integrado por dos factores: el principio de igual libertad de todas las confesiones y el de la distinción entre el orden político y el orden de las conciencias», en «Constitución Europea y cristianismo», Revista General de Derecho Canónico y Derecho Eclesiástico del Estado (4) (2004), http://www.iustel.com. Para LOPEZ GuERRA, L., «es comprensible que el artículo 9 del Convenio» de Roma «proclame la libertad religiosa, referida tanto al fuero interno como al externo, es decir, a la manifestación de las propias convicciones», en «Libertad de expresión y libertad de pensamiento, conciencia y religión, en la jurisprudencia de Estrasburgo», en RUIZ RICO, G. y RuIZ RuIZ, J. J. (dirs.), La libertad religiosa en las sociedades multiculturales..., op. cit., p. 112. 
con fines políticos, su alcance y su profundidad. Debemos aceptar los hechos de la sociología política de sentido común ${ }^{108}$.

En el caso español el debate va a girar sobre los criterios adecuados para calibrar la igualdad en la cooperación con las confesiones. Si se parte de que «el objetivo de la laicidad no es secularizar la sociedad sino garantizar la igualdad de los ciudadanos con independencia de su religión», la «dificultad radica en establecer cómo debe garantizarse esta igualdad: o bien mediante unas instituciones 'ciegas' para lo religioso, o bien con arreglos institucionales que promuevan acuerdos específicos con las religiones sean estas mayoritarias o minoritarias» ${ }^{109}$.

La respuesta constitucional al dilema no es difícil, dado el descarte de un laicismo nada neutral ${ }^{110}$. $\ll i$ La antinomia y la negación de algo -en este caso, de la religión y de toda creencia teísta- nunca son una actitud 'neutral'! ¡El ateísmo o el agnosticismo no constituyen, respecto a la religión, posiciones neutrales! En esta materia, representan posturas extremas y sumamente parciales, porque entrañan, según los casos, la negación de la verdad, del valor y de la relevancia existencial de toda religión, y en ocasiones incluso la afirmación de su índole nociva». «En cualquier caso, cierto es que una actitud política neutral no puede cerrar los ojos ante una religión que se presenta como hecho cultural tradicional o mayoritario en una determinada nación ${ }^{111}$.

108 RaWLS, J. (1993), p. 192-193; cursivas nuestras.

109 GAMPER, D. (2016), p. 97. En el fondo lo que a algunos costará entender es la laicidad positiva: «se deberá elegir entre el respeto a la estricta neutralidad estatal -que impediría cualquier forma de promoción o auspicio de alguna religión o del fenómeno religioso, entendido como algo valioso- y, de otro lado, la idea de un Estado promotor de la dimensión positiva de la libertad religiosa. La solución propuesta por una parte de la jurisprudencia y de la doctrina -que también sigue el Tribunal Constitucional peruano- es apostar por un concepto de laicidad positiva que, en nuestra opinión, es muy cuestionable y puede terminar vulnerando los derechos de libertad y de igualdad que, precisamente, pretende garantizar el principio de laicidad» cfr. MARCIANI, B. (2015), p. 250.

110 NúÑ̃EZ, L. (2006), p. 20, considera que un «Estado laico» o un «Estado neutral», «ha de ser imparcial también entre los conflictos que se puedan plantear entre una ideología laicista, que, desde este punto de vista, es solo una identidad más a tener en cuenta, y las distintas confesiones religiosas». El laicismo «vendría a vulnerar la Constitución, incurriendo, si su actitud fuera, además, recurrente, en una suerte de 'confesionalidad antirreligiosa', de todo punto inaceptable. La misma, basada en una confusión deliberada entre laicidad y laicismo, neutralidad y hostilidad, atentaría contra el principio de libertad religiosa al que, aun en su consideración más rigurosa o extrema, el de laicidad ha de acomodarse» cfr. PORRAS, J.Mª . (2006), p.132.

111 RHONHEIMER, M. (2009), p. 110. Esto es consecuencia del «tener en cuenta las creencias religiosas como factor social real del pueblo español» cfr. FERRER, J. y VILADRICH, P.J. (2010), p. 3. «La Constitución considera las creencias religiosas como un factor de la sociedad, al que los poderes públicos atribuyen relevancia jurídica» cfr. FERRER, J. (1987), p. 248. 
Desde la perspectiva laicista, por el contrario, «la libertad religiosa, más que significar el derecho del ciudadano a ejercitar su religión conforme a los dictados de su propia conciencia y con los únicos límites que marque el respeto del orden y de la moralidad pública, equivaldría a la libertad -o liberaciónque el Estado y la esfera pública lograrían de la religión y de su influjo». Esta «concepción 'laicista' de la laicidad constituye una forma -negativa, por decirlo así- de integrismo». Tiende a «anular la distinción entre poder y moralidad», al «excluir, al menos implícitamente, el hecho de que existan criterios de valor objetivos, independientes del ejercicio práctico del poder político, según los cuales pueda enjuiciarse el ejercicio del poder ${ }^{112}$.

El propio texto de la Constitución confirma el peculiar tener en cuenta el factor religioso, descartando que pueda considerarse vulnerador de la igualdad. Las críticas al respecto han de entenderse como rechazo de la opción constitucional ${ }^{113}$. Se ven contrapesadas por la actitud más comprensiva de los que, siguiendo a Habermas, se muestran sensibles a «los límites de la modernidad y anhelan el complemento que pudieran aportar las religiones». «No es que afirmen la realidad que se esconde tras las promesas religiosas, pero consideran que es difícil no interrogarse acerca de las consecuencias para la vida humana de vivir sin religión» ${ }^{114}$.

Se sugerirá pues un criterio cuantitativo, que no dejará de plantear dificultades ${ }^{115}$. $\ll$ No todas las confesiones tienen las mismas necesidades; por eso,

112 «En la actualidad, el escándalo no reside en el hecho de que el cristianismo o la Iglesia nieguen la legitimidad política y autónoma de la democracia -cosa que no hacen-sino en su pretensión de ser, también para la comunidad política democrática, una fuente y una garantía última de valor. El Estado no está ni obligado ni en condiciones de reconocer tal pretensión como verdadera. Pero tampoco puede considerar como un ataque a su laicidad la presencia pública de esa pretensión, ni su influjo en la sociedad y en la vida pública de una nación». La «imposición del ateísmo o del agnosticismo público del Estado viola uno de los requisitos esenciales de esta laicidad: su neutralidad» cfr. RHONHEIMER, M. (2009), pp. 11-112, 121, 127-128 y 134.

${ }^{113}$ SoRIANO, R. (1986), pp. 103 y 108, señala que «es frecuente la apelación al principio de igualdad religiosa en el ámbito de las relaciones interconfesionales, dejando a un lado otras clases de relaciones y hechos sociales», mientras se olvida «la cuestionabilidad de los fundamentos de la consideración jurídica privilegiada del fenómeno religioso, en contraste con otros hechos sociales: artísticos, culturales, ecológicos, relativos al bienestar social, etc.». Su crítica parece apoyarse en un problemático diagnóstico: «el bloque de los no creyentes es cada vez más sólido y no es de extrañar que pronto alcance el nivel de una abultada mayoría».

114 García Santesmases, A. (2007), p. 166.

115 «El elemento cuantitativo es «un dato esencialmente relativo, y con ese carácter ha de ser tomado en consideración, singularmente en un Estado como el español que ha sido durante siglos confesionalmente católico y en extremo intolerante con otras creencias o confesiones religio- 
a partir de la definición de una cooperación aplicable a todas ellas, se puede conceder un tratamiento distinto. Pero lo que no resulta admisible es extender unas fórmulas a unas confesiones y negárselas a otras. Cabría, como mucho, admitir la diferencia cuantitativa, pero no la cualitativa ${ }^{116}$. No soluciona el problema optar por unas «actividades positivas» de los poderes públicos, «para hacer posible el efectivo ejercicio de la libertad a todos por igual» ${ }^{117}$; porque lo que se pretende definir acaba entrando en la definición. Si se entendiese por igual un tratamiento paritario, se ignorarían las creencias vigentes en la sociedad. En realidad «la igualdad solamente se consigue cuando las distintas confesiones religiosas reciben un tratamiento específico por parte del legislador adaptado a sus peculiaridades»; parece obvio que cada confesión religiosa constituye un fenómeno peculiar, por lo que sería preciso adoptar una igualdad de proporcionalidad ${ }^{118}$.

A la hora de llevarla a la práctica podrá planear siempre la sospecha de discriminación. «Si de lo que se trata es de facilitar el ejercicio de la libertad

sas. Si sólo se atendiera a este ingrediente aritmético para determinar el notorio arraigo, se podría llegar a sostener sin exageración que sólo la Iglesia católica cumpliría con aquél requisito, pues, en comparación con el número de creyentes católicos (o de bautizados en la fe católica), todas las demás Iglesias, confesiones o comunidades religiosas ofrecen cifras muy exiguas» cfr. Leguina VilLa, J. (1984), pp. 690-691.

116 BARRERO, A. (2015), p. 56.

117 CASTRO, A. (2003), p. 2.

118 Concheiro TeIJIDO, F. A., «Algunas consideraciones sobre la naturaleza jurídica de los acuerdos españoles con las confesiones religiosas minoritarias y el principio de igualdad», en Acuerdos del estado español con confesiones religiosas minoritarias, Marcial Pons, Madrid, 1996, p. 542. «Igualdad interpretada en el sentido de dar a cada uno lo que le corresponde, y no bajo el significado de uniformidad, o sea dar a todos lo mismo; así como atendiendo a los criterios de justificación objetiva y razonable, además de a la relación de proporcionalidad entre fin perseguido y medios empleados»; evitando «una interpretación equivocada de la igualdad en el sentido de uniformidad, el querer dar a todos lo mismo y no a cada cual lo que le corresponda» cfr. OLMOS, M.E. (2006), pp. 421 y 429. En efecto, «no debe confundirse la igualdad con la uniformidad, pues cada confesión precisa, dadas sus, a menudo, muy dispares características orgánico-funcionales y diversa implantación social, un tratamiento individualizado y peculiar, razón por la que la Constitución alude a las 'consiguientes relaciones de cooperación', sugiriendo así que las mismas deben ser proporcionales y acordes con las muy concretas necesidades y pretensiones que manifiestan cada uno de los grupos religiosos existentes» cfr. PorRas, J.Ma . (2006), pp. 190-191. CAÑAMARES ARRIBAS, S., precisa que «la relación de proporcionalidad se traduce en que la ruptura de la igualdad en sí misma sólo puede estar justificada cuando se trata de amparar otros bienes jurídicos de relevancia constitucional, asegurando, en todo caso, la lesión mínima necesaria para la salvaguarda de los intereses prevalentes», en «La (des)igualdad religiosa en la tributación local: las exenciones de las confesiones religiosas en el impuesto de construcciones, instalaciones u obras y en el impuesto sobre vehículos de tracción mecánica», en Una filosofía del Derecho en acción. Homenaje al Profesor Andrés Ollero, Congreso de los Diputados, Madrid, 2015, p. 1708. 
religiosa no se entiende por qué la firma de Acuerdos con rango de ley necesita cumplir el requisito del notorio arraigo, que por muchos esfuerzos que se hayan hecho desde la Administración para interpretarlo en sentido amplio, introduce un obstáculo al ejercicio de la libertad religiosa y puede ocasionar un perjuicio o colocar en situación de desventaja a determinadas personas o grupos religiosos, dando lugar a una situación discriminatoria. En estos supuestos no se lesiona la libertad religiosa sino la igualdad» ${ }^{119}$.

Frente a ello se argumentará que «la igualdad religiosa ante la ley» consiste en «ser iguales titulares del mismo derecho de libertad religiosa», ya que lo que «prohíbe el principio de igualdad jurídica es la discriminación, o sea, 'que la desigualdad de tratamiento legal sea injustificada por no ser razonable'». Esto no impide «que el legislador pueda valorar situaciones y regularlas distintamente mediante trato desigual, pero siempre que ello obedezca a una causa justificada y razonable» ${ }^{120}$.

El asunto se complicará, como ya indiqué, cuando en la argumentación entre en juego la referencia al artículo 9.2 CE. No faltan motivos para ello, al residenciarse en él las acciones positivas, destinadas a hacer reales y efectivas la igualdad de los individuos y los grupos ${ }^{121}$; sin embargo, determinadas interpretaciones llevarían a sorprendentes efectos colaterales ${ }^{122}$. Se nos dirá

119 CASTRO, A. (2003), pp. 29-30.

${ }^{120}$ FERRER, J. (2010), pp. 1 y 2, citando la temprana STC 34/1981, de 10 de noviembre, como hará luego con la STC 109/1988, de 8 de junio, para concluir que «debe rechazarse con vigor aquella visión simplista según la cual donde hay diversidad no existe igualdad». Similar argumentación en Molano, E. (1986), p. 255, citando la STC 22/291, de 2 de julio. En realidad, como indica Moreno, M.M. (2006), p. 67, citando a GonZÁLEZ DEL VALLE, el «principio de no discriminación religiosa se dirigiría al ámbito comunitario o colectivo, de manera que las confesiones no estarían sujetas al principio de igualdad y sí al de no discriminación».

121 Como consecuencia de su matriz original, el «Estado se configura como aparato nivelador de las diferencias sociales culturales, económicas y favorece a individuos o grupos en desigualdad de condiciones a fin de alentar su participación en los beneficios y ventajas generales del ordenamiento». Se podrá convertir así en «crisol de importantes tensiones y contradicciones que repercuten especialmente en la materia religiosa» cfr. MотILLA, A. (1989), pp. 196-197 y 198.

122 Los experimenta LOPEZ-Sidro, A. (2015), pp. 309-310 y 311, que asume la entrada en juego el artículo 9.2; tendría como consecuencia que «el Estado no se limita a asistir pasivamente al ejercicio de la libertad religiosa por parte de los ciudadanos, sino que la promueve y remueve los obstáculos con que se pudiera encontrar», pero acaba sospechando que «en los últimos años han propugnado el pluralismo religioso en España, llegando a impulsar una discriminación positiva a favor de las confesiones religiosas minoritarias y con exclusión expresa de la Iglesia Católica»; a su juicio, «lo que se pretende es deslizar la idea de que lo católico está a la baja, y la pluralidad religiosa en alza. En definitiva, se quiere desdibujar la influencia de la Iglesia Católica en un 
también que la «cooperación con las confesiones religiosas matiza, sin embargo, el alcance de la separación y neutralidad y hunde sus raíces en el artículo 9.2 CE». En realidad lo que se matizará es el alcance de la neutralidad pero en modo alguno el de la separación, que es lo más contrario imaginable a la cooperación. Se añadirá con acierto que «la imperatividad jurídica de las relaciones de cooperación ha de situarse en el propio precepto que las contempla (art. 16.3) sin que pueda desprenderse directamente de la tutela prevista para los grupos del artículo $9.2 \gg^{123}$.

Cuando esto se olvida se nos propondrá una presunta «neutralidad positiva cuyo contenido entendemos que encuentra en el art. 9.2 su fundamento normativo»; haría «especial hincapié en la función que el citado precepto normativo tiene como mecanismo corrector de la desigualdad material» ${ }^{124}$. O sea, que habría que tener en cuenta las creencias de la sociedad para procurar equipararlas, ignorando el pluralismo. No se trataría, «por tanto, de respetar la libertad de conciencia y religiosa de las personas en general», sino «de garantizar -mediante medidas promocionales y de acciones afirmativas- la propia pervivencia e identidad religiosa del grupo o minoría ${ }^{125}$.

magma religioso en que ella sólo sería una más de las presencias confesionales de nuestro país, y por ello no habría que prestarle más atención que a las demás. Incluso, habría que prestarle menos, para compensar la falta de atención que han recibido las otras -cuando apenas existíanen comparación».

123 «El constituyente tuvo en cuenta la especificidad del fenómeno religioso, otorgándole un tratamiento particular. Sólo en el caso de que la Constitución no hubiera previsto directamente las relaciones de cooperación con las confesiones sería correcto reclamar para éstas la acción promocional que el artículo 9.2 brinda a los grupos sociales» cfr. BARRERO, A. (2015), pp. 40 y 49.

124 «Así pues, las medidas que obliga a establecer el 9.2 tienen como objeto no tanto la conservación del statu quo sino la transformación social, esto es, acercar a la sociedad a ese ideal de igualdad. Infringirán el mandato cuando en lugar de crear las condiciones para la igualdad aumenten las desigualdades» cfr. CASTRO, A. (2003), pp. 2 y 9.

125 CONTRERAS, J.Mª . (2005), pp. 146-147, que remite coherentemente no sólo al artículo 9.2. CE sino también al artículo 2 de la Constitución italiana. Se satisfaría así la «necesidad de adoptar políticas de reconocimiento que permitan reparar situaciones de injusticia cometidas contra ciertos grupos tradicionalmente excluidos», mientras en el caso de «las medidas de colaboración con la Iglesia católica, por ejemplo, se presentan respecto de una creencia mayoritaria y asentada, que tiene una posición dominante en la sociedad» cfr. MARCIANI, B. (2015), pp. 260261. Por el contrario: «el Estado sólo debe regular y proteger el pluralismo religioso pero nunca potenciarlo y garantizarlo porque esa actitud supondría una extralimitación en las competencias que le son propias, atentando contra la libertad religiosa y la laicidad» cfr. MORENO, M.M. (2006), p. 88. 
No poca influencia en el debate tuvo la alusión expresa a la Iglesia Católica en el texto del artículo 16.3 CE que venimos comentando. No estaba prevista en el anteproyecto constitucional, pero enmiendas de los grupos parlamentarios de UCD y AP encontraron un inesperado apoyo en el portavoz comunista Santiago Carrillo, lo que acabó doblegando la inicial reticencia del grupo socialista al respecto. Considero que su efecto fue sobre todo resaltar en qué medida la igualdad consiguiente al tener en cuenta las creencias de la sociedad española brindaría fundamento objetivo y razonable para un trato dispar a la confesión religiosa hegemónica ${ }^{126}$.

El texto en vigor no dejó de suscitar reacciones críticas. No sé si porque, como se ha apuntado, «las tendencias actuales de nuestro tiempo amparadas podría decirse bajo el lema 'la antorcha de la laicidad' realmente no van por el camino idóneo de la garantía real y el respeto del auténtico derecho de libertad religiosa, ni tampoco en pro del desarrollo de la cooperación, sino todo lo contrario, en defensa de una separación a ultranza, un laicismo hostil al factor religioso». Ello explicaría que «algunas de sus consignas, por ejemplo, 'No queremos Concordatos'; 'No a la Europa vaticana: separación de las Iglesias y del Estado' se dirigen en especial contra una determinada Iglesia, curiosamente la que más miembros tiene y la que mayor obra social realiza» ${ }^{127}$. Incluso voces más serenas dejarán entrever cierta frustración ${ }^{128}$, mientras alguna otra sonará menos serena ${ }^{129}$.

126 PRIETO SANCHIS, L., considera, en uno de los primeros comentarios sobre la Constitución, respecto a la mención a la Iglesia Católica que «la fórmula constitucional no vincula de forma decisiva la política religiosa de ningún Gobierno y carece de consecuencias jurídicas importantes», en «Las relaciones Iglesia-Estado a la luz de la nueva Constitución: problemas fundamentales», en A. PREDieri y GarCía DE EnTERría, E., La Constitución española de 1978, Civitas, Madrid, 1980, p. 330.

127 OLMOS, M.E. (2006), p. 428.

128 Apuntarán que el «camino a recorrer debería ir por atender las demandas de las plataformas laicas que reclaman una política de revisión de los Acuerdos con la Santa Sede. No se puede sostener la situación actual. Hay una contradicción entre el espíritu laico de la Constitución del 78 y los Acuerdos que se producen en enero de 1979». Esto nos habría llevado a «un Estado que no es confesional pero que tampoco es laico». Bien es verdad que esa sensación de frustración se aclara cuando se explicita cuál sería la alternativa: «es evidente que no se llega a alcanzar un modelo de república laica, semejante al que impera en Francia. Nos quedamos en un Estado no confesional» cfr. GARCÍA SANTESMASES, A. (2007), pp. 48-49, 50 y 131.

129 «La Iglesia Católica, que siempre ha sido y es el más recalcitrante adversario del laicismo», «se ha ido amoldando a los aires de la modernidad, renunciando frecuentemente a la idea del Estado católico, pero solamente in verbo, nunca in pectore, y siempre aprovechando la ocasión que pudiera favorecerla». «En España, puede decirse que actualmente impera un criptoconfesionalismo o una confesionalidad de facto» cfr. PUENTE OJEA, G. (2006), pp. 89-90. 
La especial sensibilidad de la sociedad española hacia la desigualdad ${ }^{130}$, fruto en buena parte de sus raíces católicas, llegó a suscitar algún asomo de mala conciencia en sus propias filas. Algún autor está a punto de morir de éxito al sugerir que «el status jurídico específico de la Iglesia Católica se constituye en paradigma extensivo para las demás confesiones». Ante inesperadas adhesiones entusiastas se vería obligado a matizar que es «importante advertir que con este concepto queremos indicar una cantidad y calidad de trato específico, pero no la aplicación a las demás confesiones ni del mismo contenido del status jurídico de la Iglesia católica, ni tampoco la de un único status, tan rico como el que goza la Iglesia católica pero unitario -para todo lo acatólico-, porque en ambos casos estaríamos ante un paradigma uniformador en el que no tendrían cabida los hechos diferenciales de la especificidad de cada confesión ${ }^{131}$.

Es lógica pues una disparidad de trato derivada de la igualdad consiguiente al tener en cuenta las creencias de la sociedad española; nada distinta a la experimentada en otros ámbitos, como el político, el sindical o el deportivo. La cooperación derivada de la laicidad positiva desemboca precisamente en una igualdad consiguiente.

${ }^{130}$ De La Hera, A., matizó el 22 de abril de 2008 la afirmación de la recién nombrada Ministra de Igualdad, según la cual «la igualdad es el supremo valor de la democracia». «Tan sólo aspirando, como objetivo social y político absolutamente prioritario, a la igualdad en la libertad, sacaremos algo en limpio de la igualdad como un valor. Porque la libertad, esa sí, es el supremo valor de la democracia. La igualdad es un instrumento».

131 Viladrich, P. J. y Ferrer, J. (1996), p. 142. Reiterado en (2010), p. 3, con Ferrer, J. como autor principal. MARTíNEZ TORRÓN, J. (2004), p. 17, considerará razonable en ciertos casos esa función paradigmática. «Lo que no parece tan adecuado es reservar el sistema exclusivamente para la Iglesia católica, cuando puede ampliarse, dentro de la misma lógica jurídica y sin especiales problemas, a otras confesiones religiosas. Efectivamente, el principio de igualdad aconseja extender a otras confesiones el sistema de asignación tributaria con sus perfiles actuales». 
0000 